\title{
Why Do Politicians Shift? A Gender- Based Study of I and We in Joint Political Press Conferences
}

Dr. Marwa Mohamed Khamis El-Zouka

English Department-Faculty of Arts

Alexandria University 


\section{Abstract \\ Why Do Politicians Shift? A Gender-Based Study of I and We in Joint Political Press Conferences}

In joint political press conferences, politicians use language to realize different functions and political goals. One important language aspect that is used functionally in joint political press conferences is personal pronouns. Using Goffman's (1981) concepts of participation framework and footing, the present study investigates the similarities and/or differences between male and female politicians in changing footing by shifting from $I$ to we and vice versa in joint political press conferences. It also examines the reasons for making these shifts. Results indicate that male and female politicians shift between $I$ and we the same number of times in the speech sessions. However, in the question-answer sessions, male politicians shift between these two pronouns more than their female counterparts. Results also show that male and female politicians shift from $I$ to we and vice versa for various reasons such as talking about achievements and stating opinions in the speech sessions, and expressing a stance and shedding light on future acts or hopes in the question-answer sessions. Some of the reasons for making the pronominal shifts in question are common between male and female politicians while others are not. By alternating between $I$ and we, male and female politicians alternate between their individual and institutional identities.

Keywords: gender differences, joint political press conferences, personal pronouns, participation framework, footing.

$$
\text { الملخص باللغة العربية }
$$

$$
\text { لماذا يقوم السياسيون بالتغيير؟ دراسة نوعية لاستخدام "أنا" و "نحن" في المؤتمرات الصحفية السياسية }
$$

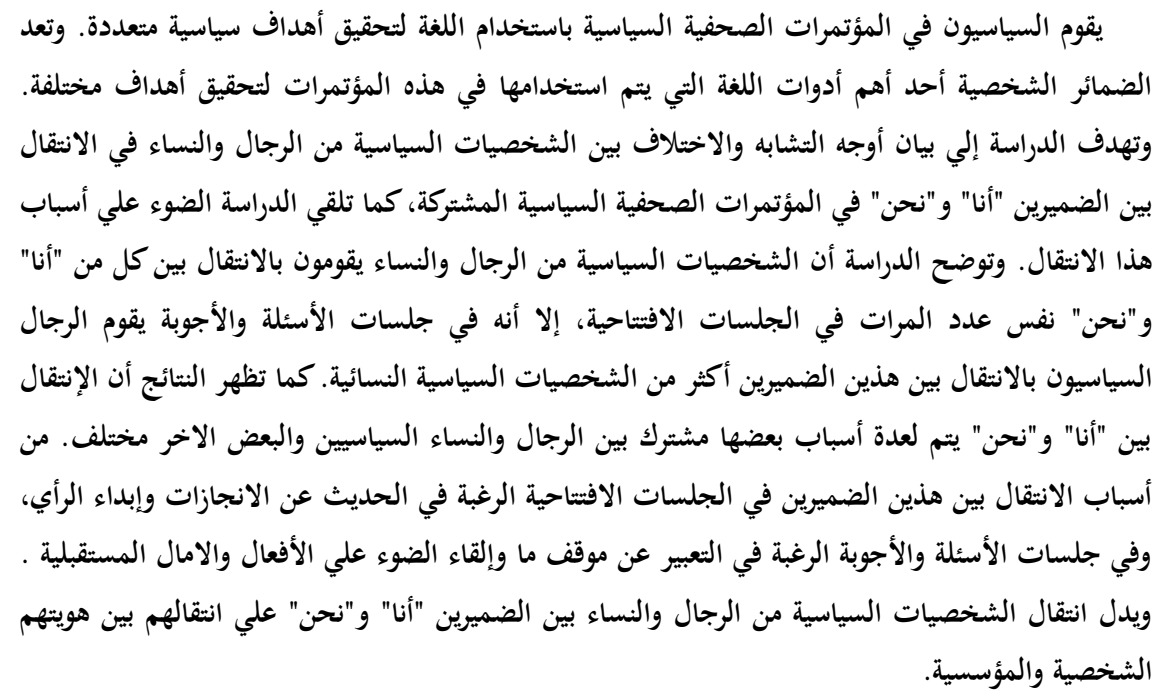




\section{Introduction}

Language plays an essential role in politics since political actions and activities are prepared, influenced and performed by language. Political language conveys information, reflects plans and proposals, announces and explains policies, and expresses political ideologies, all of which have direct impacts on people's lives as well as on the relationship between countries. In joint political press conferences, politicians announce the outcome of their meetings. In these conferences, politicians use pronouns for several purposes, including expressing their ideologies on political issues that are of common interest, showing and fostering a sense of solidarity, and constructing identities. Male and female politicians may differ in this respect, i.e. they may use pronouns to achieve certain political goals.

\section{Aims of the Study}

When people address each other, the choice of personal pronouns is determined by the relation between the participants, their intended communicative goals, and the context in which the interaction takes place. This is seen in joint political press conferences in which politicians, even if they hold different ideological positions, tend to indicate solidarity by showing a shared understanding of each other's political ideologies and policies. In this context, politicians' communicative goals may vary and so they can use pronouns to:

indicate, accept, deny or distance themselves from responsibility for political action; to reveal ideological bias; to encourage solidarity; to designate and identify those who are supporters (with us) as well as those who are enemies (against us); and to represent specific idiosyncratic aspects of the individual politician's own personality (Wilson, 1990: 76). 
According to Moberg and Eriksson (2013: 320), personal pronouns are all "political in the sense that they are involved in struggles over representation." In addition, in joint political press conferences, politicians' choice of personal pronouns can be associated with their roles and identities since politicians can talk as representatives of a party, members of the government, or as individuals.

In light of the above, the present study seeks to answer the following research questions:

1- Are there similarities and/or differences between male and female politicians in employing shifts between the two first person pronouns $I$ and we in joint political press conferences to construct different identities and express their political ideologies?

2- Why do male and female politicians make these pronominal shifts in the joint political press conferences under analysis?

The two pronouns $I$ and we have been chosen because the shifts between them are the most frequent in the analyzed data. The study also investigates the reasons for shifting between $I$ and we, and provides frequency counts for these reasons as well as for the number of shifts between the two pronouns under investigation.

\section{Data and Methodology}

The data for the present study consists of four joint political press conferences whose transcripts have been downloaded from the Internet. The first press conference was held between former U.S. Secretary of State, Condoleeza Rice, and former Australian Foreign Minister, Stephen Smith, on July 25, 2008. The second press conference was held on May 17, 2010 between Anders Fogh Rasmussen, NATO Secretary General, and Madeleine Albright, Chair of the Group of Experts on NATO's New Strategic Concept. The third was held on November 16, 2011 between U.S. President, Barack Obama, and former Australian Prime Minister, Julia Gillard, and the fourth press conference was held on April 24, 2012 between 
former U.S. Secretary of State, Hillary Clinton, and former Australian Minister for Foreign Affairs, Senator Bob Carr. The full transcripts of the analyzed joint political press conferences are given in appendices (1) to (4).

Goffman's (1981) concepts of participation framework and footing are used as a framework for the analysis of the data. The analysis is carried out quantatively and qualitatively. In the former, the data is examined to determine the number of changes in footing realized through pronominal shifts between $I$ and we that male and female politicians make in the speech sessions and question-answer sessions. In the latter, the speech sessions and question-answer sessions are examined separately and instances of change in footing are identified. Representative examples of pronominal shifts are given and analyzed to show how male and female politicians change footing using pronominal shifts to realize political goals.

\section{Theoretical Background}

\subsection{Gender Studies}

Differences in the way language is used by males and females has long attracted scholars' attention and been the subject of their research. Jesperson's (1922) study is one of the first academic studies that examines the relation between language and gender. In this study, Jesperson identifies a number of male-female lexical variations, and shows that men can coin new words but women are less inventive and their vocabulary is less extensive than that of men. He also claims that women have a fondness for hyperbole, favoring adverbs of intensity like "awfully pretty" and "terribly nice". These are often used without regard to their proper meaning (Jesperson, 1998: 235-237). Since then, scholars have attempted to study men's and women's different ways of talking, and developed three frameworks for this purpose. These are: the deficit framework, the dominance framework, and the difference framework. 
The deficit framework, represented by lakoff's (1975) study, refers to "any approach which interprets male-female linguistic differences as evidence for women's powerlessness and subordinate status vis-à-vis men" (Speer, 2005: 22). In the dominance framework, developed by Spender (1980), "women are quite literally dominated by men in their talk, in terms of both the amount they talk, and their control over the topic" (Speer, 2005: 26). The difference framework, associated with Tannen's (1990) work, is based on the view that males and females "have different but equally valid styles" (Tannen, 1990: 15).

Scholars' interest in examining gender differences in using language is seen in the plethora of research carried out in this respect. For example, Mulac, Seibold, and Farris's (2000) study indicates that men use more words, while women use longer sentences. Studies by Biber, Conrad, and Reppen (1998), Mehl and Pennebaker (2003), and Mulac, Bradac, and Gibbons (2001) show that women use more conjunctions, intensive adverbs, and modals than men. In addition, Mehl and Pennebaker (2003) and Mulac and Lundell (1986) prove that men use more articles and longer words than women. In studying males' and females' use of pronouns, Mulac et al. (2001) show that men use the first person singular pronoun more often than women, while Mehl and Pennebaker's (2003) study reports the opposite.

Gender differences in using language has been explored in political discourse which "has often been identified as a male domain, with women excluded or at best relegated to the role of interloper" (Lakoff, 2003:176). However, because political discourse is ideological, it is "the site where politicians' multiple ideological identities are enacted: By definition, they speak as politicians, but also as conservatives or liberals, men or women, feminists or anti-feminists, racists or anti-racists, and so on" (Van Dijk, 2003: 214-215). Some of the studies that have investigated gender differences in political discourse are: Fracchiolla (2011), 
Kahn (1992; 1996), Maitland \& Wilson (1987), Perry (2005), and Wilson (1990).

\subsection{Political Press Conferences}

Political press conferences are a subcategory of the genre of press conferences which covers many areas, including law, business, sports, medicine, and politics. They could either be singleparty or two-party. Single-party conferences take place between a politician and reporters whereas two-party press conferences are held between "two political leaders in a ritualized communicative event, with the objective of projecting a united front on crucial global political issues" (Bhatia, 2006: 176).

Single-party and two-party political press conferences are composed of a speech session followed by a question-answer one. The conferences open with the speech session in which the politician hosting the event gives a speech to explain the policy and motives behind his/her meeting with the guest politician. This is followed by a question-answer session in which the politician(s) answers journalists' questions. Because the politicians' press conferences are then reported in different media, the politicians have to present their policy in a comprehensible way and answer journalists' questions adequately because acting differently can have negative consequences for the publicity of their ideas (Moberg \& Eriksson, 2013: 316). Have (1999: 43) indicates that the structure of political press conferences has four sequences. These are:

1- The Opening sequence: This is where the host politician starts the press conference by welcoming the guest politician and saying that their meeting was successful.

2- The individual voices: This is where politicians make individual statements on a number of issues or topics. The host politician gives his/her statement first then invites the guest politician to give his/hers. 
3- The interactional sequence: This is a question-answer session which is controlled by the politicians, and in which reporters ask questions and politicians answer them.

4- The closing sequence: This is a brief sequence where the host politician ends the press conference by thanking the guest politician, the journalists, and the audience.

Participants in joint political press conferences are the two politicians and journalists asking questions. The audience of the press conferences is not just the journalists or other media authorities but also "the international community of politicians and more importantly the general public who are being represented by their leaders" (Bhatia, 2006: 177). What politicians say in political press conferences, as well as mediated face-to-face political events, is just a staging of spontaneous interactions (Holly, 1989: 129). In other words, all that is said in political press conferences is not spontaneous. Rather, the speeches given by politicians in press conferences, as well as answers to political questions, are prepared in advance by trained specialists. Topics are also determined beforehand. Therefore, political press conferences are ritualized in nature (Bhatia, 2006: 177).

Because political press conferences are often aired, they are made accessible to national and international audiences. Thus, they - political press conferences - are not considered part of political discourse but also media discourse because they "are held more for the benefit of the general populace and members of the media who construe and attach motive to what political figures say, in part creating the reality we are familiar with" (Bhatia, 2006: 176). In light of this, airing political press conferences helps the public know about the goings-on in the political sphere as well as the ideologies of politicians. The media can also affect the public's opinion of their political leaders. Thus, political strategies include media strategies as they - media strategies - affect political efficiency and political trust (Moy \& Scheufele, 2000: 750). 
In political press conferences, politicians speak as representatives of their governments and countries, so they know that their image could be tarnished because of their use of language (Bhatia, 2006: 177; Holly, 1989: 129). Therefore, politicians employ diplomatic language as it is considered "the tactical usage of rhetoric for diplomatic resolution between both parties" (Cheng, 2002: 310).

Because political discourse has become an instance of media communication, the study of how politicians use pronouns in this context has become particularly important. Moreover, fundamental to press conferences is the use of personal pronouns to construct identities, express ideologies, and indicate interpersonal relationships. Thus, personal pronouns are key to achieving several communicative political purposes.

\subsection{Personal Pronouns}

That the choice of personal pronouns signifies the interpersonal relationship between speakers and hearers is indicated by Brown and Gilman (1960). In their pioneering work, they examine the $\mathrm{T} / \mathrm{V}$ distinction of second-person pronouns found in Indo-European languages. They distinguish between the ' $\mathrm{T}$ ' form, which is grammatically singular and is considered more familiar and informal since it refers to how persons of higher status address those of lower status, and the ' $\mathrm{V}$ ' form which is plural and more formal since it determines the way in which persons of lower status address those of higher status. Thus, a reciprocal and symmetrical use of personal pronouns indicates solidarity between speakers and hearers while a non-reciprocal and asymmetrical use reflects the power relations between them (Chen, 2006: 113; Jaworski \& Galasinski, 2000: 35; McConnell-Ginet, 2003: 79).

Chilton and Schäffner (1997: 207) have noticed that "many ordinary people in their everyday life have the feeling that politicians and political institutions are sustained by 'persuasive' or 
'manipulative' uses of language of which the public is only halfaware." One aspect of language that politicians can manipulate when addressing their audience, as well as their political opponents, is personal pronouns. These are multifunctional since they are used to fulfill various political goals in different political contexts. Because pronouns replace nouns or noun phrases, their meaning is context-dependent and thus their use can be manipulated by politicians according to their intended goals. Accordingly, the first person singular and plural pronouns can be used by politicians "to gain the people's allegiance, to have them believe that the decisions that are being made are the right ones" (Wilson, 1990: 71). Thus, the first person pronouns are particularly important in political discourse as "they...legitimize or presuppose the legitimacy of the speaker" (Chilton \& Schäffner, 1997: 217).

According to Proctor and Su (2011: 3252), "political language is a constant clash between 'us' and 'them'". Therefore, politicians' pronominal choices reflect how they identify themselves with the audience as well as other politicians, groups, and parties. Thus, beside expressing an opinion or showing the authority of the speakers, the pronoun $I$ can be used to show compassion and create a relationship with the audience. It can also be used to show commitment to the audience for future actions. Politicians can also use $I$ to present themselves positively compared to other politicians or to distance themselves from shared responsibility for any undesired actions (Beard, 2000: 45; Bramley, 2001: 27-28).

The pronoun we can be inclusive or exclusive. Inclusive we refers to the speaker, hearer, and possibly other people. It can be used to express solidarity. Exclusive we excludes the listener and includes the speaker and other groups. It can be used to share responsibility, thereby making others responsible for or involved in particular issues. The pronoun we can also have a generic meaning as we "the nation" or we "humankind" (Inigo-Mora, 2004: 35; Wilson, 1990: 49). Moreover, the first person plural pronoun we 
creates a "room" in which speakers and listeners are positioned (Chilton \& Schäffner, 1997: 217). It can be used to create a sense of solidarity with the audience and/or other groups or politicians. It also expresses an institutional identity when politicians speak as a representative of a group or on behalf of an institution. Therefore, we functions as an identity cue which "selects the relevant group, according to different specific contexts, languages, and cultures" (Bazzanella, 2002: 249).

Kitagawa and Lehrer (1990) hold that personal pronouns, including the second-person pronoun you, have three uses: referential, impersonal, and vague. They distinguish between these uses by maintaining that "Referential uses identify specific individuals...An 'impersonal' use of a pronoun applies to any/or everyone. A 'vague' use applies to specific individuals, but they are not identified, or identifiable, by the speaker" (Kitagawa \& Lehrer, 1990:742).

While the referential uses of the second-person pronoun identify individuals, the impersonal uses identify "one or more persons, but no specific person is picked out..." (Kitagawa \& Lehrer, 1990: 740). In this case, you is employed for indefinite reference. This indefinite use of you is expressed by Kitagawa and Lehrer (1990) who, by adopting Laberge and Sankoff's (1979) characterization of the indefinite use of tu/vous, point out that the impersonal you expresses the theme of generality. In other words, speakers can employ the impersonal you to convey a generally admitted truth or express a personal opinion that they hope would be shared (Kitagawa \& Lehrer, 1990: 742). This is in line with what has been called a formulation of morals and truisms which refers to the use of you to "reflect upon a kind of conventional wisdom as opposed to actual experience" (Wilson, 1990: 57).

The impersonal you can also be replaced by the indefinite pronoun one. Kitagawa and Lehrer also hold that the impersonal use of you cannot exclude in its reference what its normal (deictic) use 
would signify. For example, the addressee cannot be excluded from the reference of impersonal you by a phrase such as "I don't mean you personally" (Kitagawa \& Lehrer, 1990: 742).

Kitagawa and Lehrer (1990: 743-744) highlight the difference between the impersonal and vague usage of the second person pronoun. Although the specific referents of vague you are identified, the indefinite one cannot replace you as in impersonal pronouns. In addition, while impersonal you includes everybody, including the addressee, vague you does not include the addressee as a referent. The hearer is addressed as the representative of the intended referent in both impersonal and vague you. In the former, he/she represents all humanity whereas in the latter he/she represents a subgroup (e.g. Americans in charge of the political/military decisions). Finally, you used impersonally resists the pronoun shift in indirect quotation unlike vague you which allows the pronoun shift in indirect quotation.

The scope of reference of the second person pronoun you can be wider than that of the direct co-participant. It can be used in the singular to refer to a single person or in the plural to refer to more than one person, i.e. a group of singled-out co-participants such as a subgroup of the face-to-face audience. It can also be used to refer to an unspecific group such as a political party. In this case, you does not refer to a specific individual but rather to the individual as a representative of that group or party (Bull \& Fetzer, 2006: 5, 11).

\subsection{Participation Framework and Footing}

A politician's use of personal pronouns in political press conferences reflects his/her stances and attitudes as well as relationship with the other politician and the audience. Thus, the use of personal pronouns is related to Goffman's (1981) concepts of participation framework and footing. Goffman (1981: 3) defines participation framework as follows: "When a word is spoken, all 
those who happen to be within perceptual range of the event will have some sort of participation status relative to it." Participation framework, thus, refers to the different roles played by participants involved in a given interaction or setting.

Footing is "the alignment of an individual to a particular utterance..." (Goffman, 1981: 227). A change of footing implies "a change in the alignment we take up to ourselves and the others present as expressed in the way we manage the production and reception of an utterance" (Goffman, 1981: 128). In other words, the concept of footing refers to the speaking and hearing roles taken up by participants in interaction. This concept helps explore the nature of involvement and participation in interaction as Goffman (1981) argues that participation is not a simple either/or matter in which one party talks while the other listens. Rather, there are different degrees of participation. For example, speakers may take up various footings in relation to their remarks (Bull \& Fetzer, 2006: 9; Clayman, 1992: 165; Ensink, 1997: 9). Goffman maintains that the speaker has three roles: animator, author, and principal. $\mathrm{He}$ explains that:

The term 'speaker' is central to any discussion of word production, and yet the term is used in several senses, often simultaneously and (when so) in varying combinations, with no consistency from use to use. One meaning, perhaps the dominant, is that of animator, that is, the sounding box from which utterances come. A second is author, the agent who puts together, composes, or scripts the lines that are uttered. A third is that of principal, the party to whose position, stand, and belief the words attest (Goffman, 1981: 226).

In other words, while the animator is the person who presently utters the words, the author is the composer of the words 
that express the message. The principal is the person whose position, beliefs, and viewpoints are expressed in the uttered words.

Shifts in participation framework are expressed by shifts in footing which enables speakers, depending on what they want to achieve, to show more or less involvement, association with or detachment from a particular group, person, or position. Shifting footing is also related to the construction of identity, i.e. who the speaker, when addressing the audience, talks as: as an individual, as a representative of a group, or some other identity. The change in alignment, i.e. footing, can be marked in many ways, one of which is the use of personal pronouns.

The use of personal pronouns in political discourse has been mainly studied in political interviews (Bramley, 2001; Bull \& Fetzer, 2006; Karapetjana, 2011; Rendle-Short, 2007) political debates (Jaworski \& Galasinski, 2000; Kuo, 2002; Proctor \& Su, 2011) and political speeches (Adetunji, 2006; Allen 2006; De Fina, 1995; Maitland \& Wilson, 1987). Although there have been some studies of presidential press conferences (Clayman, 2006; Clayman, Elliott, Heritage, \& McDonald, 2006; 2007; Clayman \& Heritage, 2002; Davis, 1997; Ekström, 2009; Eshbaugh-Soha, 2003; Smith, 1990), little scholarly attention has been given to joint political press conferences (Banning \& Billingsley, 2007; Bhatia, 2006; Moberg \& Eriksson, 2013). Unlike the present study, Moberg and Eriksson's (2013) study examines how politicians use the personal pronoun we "to express unity despite diverging ideological views" (Moberg \& Eriksson, 2013: 315). Moreover, even though researchers have examined gender differences in the political arena (Fracchiolla, 2011; Khalida, Sholpan, Bauyrzhan, \& Ainash, 2013; Maitland \& Wilson, 1987; Proctor \& Su, 2011), no studies have examined gender differences in joint political press conferences. The use of personal pronouns by male and female politicians has not also been studied. Therefore, the present study seeks to fill these gaps by exploring gender differences in the use of pronominal shifts 
between the first person singular and first person plural pronouns $I$ and we in joint political press conferences to construct their identities and express their political ideologies.

\section{Analysis}

In the press conferences under analysis, male and female politicians employ personal pronouns to shift footing and thus construct different identities and express different ideologies. The focus of analysis is on the shift from the first person singular pronoun " $I$ " to first person plural pronoun "we" and vice versa.

\subsection{The Speech Sessions}

\subsubsection{Male-Female Use of Pronominal Shifts from " $I$ " to " $w e$ "}

In the speech sessions, male and female politicians change footing by employing a pronominal shift from $I$ to we for four reasons: speaking about future acts or hopes, talking about past actions, stating achievements, and indicating positive acts taken by their governments or countries. In examples (1) and (2), a pronominal shift from $I$ to $w e$ is employed to talk about future acts or hopes.

\section{Example (1)}

President Obama: As Julia described, we are increasing our cooperation -- and I'd add, America's commitment to this region. Our U.S. Marines will begin rotating through Darwin for joint training and exercises. Our Air Force will rotate additional aircraft through more airfields in Northern Australia...We'll enhance our ability to train, exercise, and operate with allies and partners across the region...

$$
(16 / 11 / 2011)
$$

President Obama here talks about the cooperation between the United States and Australia. He uses an author-based footing in "... and I'd add, America's commitment..." to indicate that, as President of the United States, he will give further information on 
this matter concerning "America's commitment to this region." Obama then shifts from author to principal in "We'll enhance our ability to train, exercise, and operate with allies and partners across the region..." as he speaks as a representative of the U.S. administration, and starts saying the future acts that will be taken by the U.S. administration in the region.

\section{Example (2)}

Hillary Clinton: As I said to the Foreign Minister today, we are hoping that by the NATO summit in Chicago, other partners will also be making their commitments to the future of Afghanistan. The Afghan National Security Force will need some $\$ 1.3$ billion from the international community to sustain their efforts over the coming year that will be added to the $\$ 500$ million committed by the Afghans and the commitment that the United States is making.

$(24 / 4 / 2012)$

Former U.S. Secretary of State, Hillary Clinton, talks about the discussions she had with former Australian Minister for Foreign Affairs, Bob Carr, concerning the transition in Afghanistan. She first uses an author-based footing $I$ to refer to her statement to her Australian counterpart and then shifts to a principal-based footing we which is seen as referring to the U.S. administration and speaks of its future hope "that by the NATO summit in Chicago, other partners will also be making their commitments to the future of Afghanistan."

Shifting from $I$ to we to talk about past actions is shown in examples (3) and (4).

\section{$\underline{\text { Example (3) }}$}

Minister Smith: And I think, Secretary, at Mercedes, people were very much impressed by your commitment to education, what education can do in terms of opportunity, but also your commitment to treating people equally, irrespective of race, color, 
religion. We've just come from Swanbourne Barracks with the SAS, where we paid our respects to the contribution that the SAS and Australian Defence and combat services generally make. We also met families from servicemen who have died in Afghanistan or in the Middle East in the course of the service for their country.

$(25 / 7 / 2008)$

In this example, Stephen Smith, former Australian Foreign Minister, tells the audience about what he and former U.S. Secretary of State, Condoleeza Rice, did in the course of the day. Smith showed Rice "some of the attractions of Perth including Mercedes College." Smith uses the first person singular pronoun I in "And I think..." to tell Rice his viewpoint concerning what people at Mercedes feel about her commitment to education and equality. He then changes footing by shifting from $I$ to we in "We've just come from Swanbourne Barracks..." to continue saying what he and Rice did during her visit to Australia.

\section{Example (4)}

Hillary Clinton: I welcomed Prime Minister Gillard's statement last week committing to support the Afghan National Security Forces after 2014, and I look forward to working with Australia and other partners on ways to make sure that any funds are spent transparently and with full accountability. Finally, we discussed a number of regional issues, including North Korea's recent missile launch, the encouraging political and economic reforms taking place in Burma...We also discussed ways to better coordinate our engagement in the Pacific Islands as well as upcoming efforts at the ASEAN Regional Forum in Cambodia.

$(24 / 4 / 2012)$

In the above example, former U.S. Secretary of State, Hillary Clinton, uses the first person singular pronoun $I$ to express her feelings towards both the statement made by Julia Gillard, 
former Australian Prime Minister, concerning a commitment "to support the Afghan National Security Forces after 2014..." and " working with Australia and other partners on ways to make sure that any funds are spent transparently and with full accountability." As is customary in the speech sessions of political press conferences, politicians make known what went on in their meetings. This explains Clinton's shift from I to we in "Finally, we discussed a number of regional issues..." in which she changes footing to say what she and former Australian Foreign Minister, Bob Carr, discussed in their meeting which took place prior to the joint press conference. Thus, Clinton here shifts to we to refer to past actions.

In examples (5) and (6), male and female politicians shift from " $I$ " to "we" to refer to certain achievements.

\section{Example (5)}

Bob Carr: On the Gettysburg battlefield on Sunday with Ambassador Beazley, I was reminded of the soaring words of Lincoln "government of the people" and that's what unites us. This nation, the United States, conceived the Constitution in the 1790 s to give effect to that notion of government by the people. And Australians have adhered to democratic values ever since we won self-government in the middle of the 19th century.

$(24 / 4 / 2012)$

In this example, Senator Bob Carr, former Australian Minister for Foreign Affairs, talks about the relationship between Australia and the United States. He first adopts an author-based footing using $I$ to say that being on the Gettysburg battlefield reminded him of Lincoln's words "government of the people" and that the United States gave effect to that notion ever since the Constitution was enacted in the 1790s. Bob Carr then changes 
footing by shifting from author $I$ to principal we to talk about Australians and refer to the achievement they made in the middle of the $19^{\text {th }}$ century by winning self-government.

\section{Example (6)}

Prime Minister Gillard: President Obama and I have been discussing the best way of our militaries cooperating for the future. So I'm very pleased to be able to announce with President Obama that we've agreed joint initiatives to enhance our alliance -- 60 years old and being kept robust for tomorrow.

$(16 / 11 / 2011)$

In example (6), former Australian Prime Minister, Julia Gillard, says that President Obama and herself discuss how the militaries of the United States and Australia agree on future cooperation. Gillard adopts an author-based footing $I$ to express her pleasure with the announcement she's making to the audience. She then shifts to a principal-based footing to refer to an important achievement, namely the agreement made between the two countries concerning joint initiatives to enhance their alliance.

Examples (7) and (8) demonstrate the shift from $I$ to we by male and female politicians to talk about the positive acts taken by their governments regarding some important issues.

\section{Example (7)}

President Obama: I very much wanted to take this trip last year, and although events back home prevented me from doing so, I was determined to come for a simple reason: The United States of America has no stronger ally than Australia. For nearly a century, we've stood together in defense of the rights and freedoms that we cherish.

$(16 / 11 / 2011)$ 
In this example, President Obama adopts an author-anchored footing as he uses the first person singular pronoun $I$ to talk about his thoughts concerning the trip to Australia ("I very much wanted to take this trip last year... I was determined to come for a simple reason..."). Obama then changes footing as he shifts from $I$ to principal we to refer to the positive acts that make the United States and Australia strong allies. These include being standing together in defense of the freedoms that both countries cherish.

\section{$\underline{\text { Example (8) }}$}

Madeleine Albright: I think that what is new in this report is that the report is the first opportunity to reflect on what NATO has done since the last strategic concept in 1999... And therefore I think this new concept of partnership is something that needs to be focused on much more. We call for enhanced partnerships for many nations and other international organizations and non-governmental entities. We also call for enhanced political consultations and crisis management mechanisms. And we are looking at ways how to deal with new threats from non-State actors.

$(17 / 5 / 2010)$

In his example, Madeleine Albright uses the first person singular pronoun $I$, thereby adopting an author-anchored footing, to express her opinion on the report prepared by the group of experts on NATO's new strategic concept. She then shifts footing as indicated by shifting from $I$ (author) to we (principal) to talk, as chair of the group of experts, about some positive acts made by NATO "We call for... actors".

\subsubsection{Male-Female Use of Pronominal Shifts from "we" to " $I$ "}

In addition to changing footing in the speech sessions by shifting from author $I$ to principal we, male and female politicians also change footing by shifting from principal to author. They do so 
to express an opinion, as shown in examples (9) and (10), and feelings, as shown in examples (11) and (12).

\section{Example (9)}

Minister Smith: This morning, we started off with coffee in Mount Lawley, at the suburb that my family have lived in since 1967, and I was pleased to be able to introduce my mum and dad and my son and, subsequently, my daughter, to the Secretary. We then went to Mercedes College in Perth, and I think there it's true to say that the power of education and the power of equality can open up anything for any young woman or, indeed, for any young man, Australian, American, of whatever nationality.

$(25 / 7 / 2008)$

In this example, former Australian Foreign Minister, Stephen Smith, uses the first person plural pronoun we to refer to the activities that he and former U.S. Secretary of State, Condoleezza Rice, carried out "...we started of...1967"). Then he shifts to $I$ to refer to a personal feeling ("...I was pleased to...") and to we again to resume saying the activities made ("We then went..."). To express his opinion, on education and equality, Stephen Smith shifts from we to I in "... and I think..."

\section{Example (10)}

Madeleine Albright: That it is important that at this stage we understand who we are and how we're going to operate. I think that what is new in this report is that the report is the first opportunity to reflect on what NATO has done since the last strategic concept in 1999.

$(17 / 5 / 2010)$

Madeleine Albright here employs the first person plural we as she talks about the need for NATO to deal with the $21^{\text {st }}$ dangers 
because the threats that face the Alliance in the $21^{\text {st }}$ century "are so totally different". Therefore, it is necessary to understand "who we are and how we're going to operate". Albright then shifts from we to $I$ to give her opinion on the report as it "is the first opportunity to reflect on what NATO has done since the last strategic concept in 1999".

\section{Example (11)}

President Obama: In this work, we're deeply grateful for our alliance with Australia and the leadership role that it plays. As it has been for six decades, our alliance is going to be indispensable to our shared future, the security we need and the prosperity that we seek not only in this region but around the world. I'm also very grateful for my partnership with Prime Minister Gillard.

$(16 / 11 / 2011)$

In this example, President Obama talks about the relation between the United States and Australia. The first person plural pronoun we used in "...we're deeply grateful...the security we need and the prosperity that we seek..." refers to Obama and the American administration. Obama then shifts from we to $I$ in "I'm also very grateful..." By so doing, he changes footing from principal we to author $I$ to express his own personal gratitude to former Australian Prime Minister, Julia Gillard, for her partnership with him.

\section{Example (12)}

Hillary Clinton: With respect to today's meeting with Minister Carr and myself, it represents what is one of the world's strongest and most productive alliances... So it is fitting that we discussed a wide range of bilateral, regional, and global issues. We discussed the steps we are taking together to strengthen our military alliance, which helps underwrite security and stability in the Asia-Pacific. 
As President Obama and Prime Minister Gillard announced last year, U.S. Marines will begin rotating through Darwin for joint training and exercises. In fact, the first contingent of 200 Marines arrived earlier this month, and $\mathbf{I}$ thanked the Minister for the very warm welcome they received.

$(24 / 4 / 2012)$

In this example, former U.S. Secretary of State, Hillary Clinton, uses the first person plural pronoun we to include herself and former Australian Minister for Foreign Affairs, Bob Carr, and shed light on what went on during their meeting saying, "...we discussed...alliance..." To express her gratitude to Bob Carr for warmly welcoming U.S. Marines for "joint training and exercises", she shifts from we to $I$ in "and I thanked the Minister for the very warm welcome they received."

Example (13) shows one reason for which female politicians, unlike male politicians, adopt a pronominal shift from $w e$ to $I$. This reason is: making personal comments.

\section{Example (13)}

Secretary Rice: ...we've defended freedom together. But the reason that we've defended freedom together is we share much more. We share values and we share a fierce determination to defend our way of life and to defend our freedom. And there is no better friend for the United States than Australia. We -- of course, in speaking to the families, I want to note to the people of Australia that the sacrifice that they've endured, of course, can never fully be repaid.

$(25 / 7 / 2008)$

Former U.S. Secretary of State, Condoleezza Rice, uses the first person plural pronoun we in talking about the United States and Australia to shed light on what makes them "share a wonderful and productive and effective alliance" saying, "...we've 
defended...defend our freedom." Rice then shifts from we (principal) to $I$ (author) to make a personal comment to Australians about the sacrifice they have endured after losing their beloved ones in the course of serving their country.

\subsection{The Question-Answer Sessions}

\subsubsection{Male-Female Use of Pronominal Shifts from " $I$ " to " $w e$ "}

In the question-answer sessions in the analyzed press conferences, male and female politicians make a pronominal shift from the first person singular pronoun $I$ to the first person plural pronoun we to express a stance, shed light on future acts or hopes, and talk about past actions. The first of these uses is shown in examples (14) and (15).

\section{Example (14)}

Question: Secretary Clinton can you tell us your thoughts when you found that your Australian counterpart was suddenly, perhaps inexplicitly, no longer Kevin Rudd and someone you'd got to know reasonably well but now Bob Carr, former State Premier of New South Wales who had retired from politics. And Senator Carr, it made headlines internationally and in Australia last week when the Gillard government announced troops would be withdrawn from Afghanistan in 2013 - a year earlier than previously intended. There are now considerable efforts by the Australian government to say there's no change. Could you tell us what is it? And how did you explain it to Secretary Clinton?

Bob Carr: The message I've had since I took over as Australian Foreign Minister barely six weeks ago is one of continuity. I'm continuing the work of Kevin Rudd. This continuity runs through years of Australian foreign policy and what we're about here, working on the Australian American partnership, is bipartisan consensus in Australia.

$(24 / 4 / 2012)$ 
In this example, former Australian Minister for Foreign Affairs, Bob Carr is asked about the announcement made by the Gillard government concerning withdrawing troops from Afghanistan in 2013, "a year earlier than previously intended." Yet, he does not start his answer by tackling this issue. Rather, he first comments on the journalist's question to Hillary Clinton although he was not asked to do so. It was Hillary Clinton who, by being addressed by referential you, was expected to provide her thoughts concerning working with Bob Carr "who had retired from politics" and no longer with Kevin Rudd, her Australian Counterpart then. In his comment, Bob Carr adopts an author-anchored footing using $I$ to talk about his message since he became Australian Foreign Minister ("The message I've had...Rudd"). He then changes footing by shifting from $I$ to we in "...and what we're about here is bipartisan consensus in Australia" to emphasize Australia's partnership with America. He wants to make it clear that regardless of who the Australian Foreign Minister is, the stance of Australian government does not change; it depends on the element of continuity which "runs through years of Australian foreign policy."

\section{Example (15)}

Question: Secretary Albright, just follow-up of the question of my colleague. In the current geopolitical circumstances, do you consider any geographical limits for NATO open door policies?

Madeleine Albright: I think that we restated that NATO should retain an open door policy based on the previous criteria that have been used. And we also made very clear that NATO is an entirely voluntary organization. So the guidelines and criteria that have been used for previous membership is the same; will continue the same.

$(17 / 5 / 2010)$ 
In this example, the journalist's use of vague you gives Madeleine Albright the chance to answer as an author or principal. In her reply, Albright adopts an author-based footing using the first person singular pronoun I saying, "I think". She then shifts to a principal-anchored footing using we to talk in her institutional identity as a member in NATO, thereby indicating a high degree of involvement with the members of this organization. Madeleine Albright shifts from $I$ to we to explain the stance of NATO concerning its open door policy saying that it is "based on the previous criteria that have been used" and she emphasizes this stance by using the verb "restated".

Shifting from $I$ to we to shed light on future acts or hopes is seen in examples (16) and (17).

\section{Example (16)}

Question: ... Mr. President, I wanted to ask you about the other rising giant of our region -- India -- and the Prime Minister might like to add some comments. How significant is it for the U.S. that Australia is now considering selling uranium to India? And could you clear up for us what influence or encouragement your administration gave Australia as it made that decision? And also, the decision is so India can produce clean energy. In that regard, you're aware that our Parliament has passed a new bill, pricing carbon -- a carbon tax, if you like. But we're intrigued about where America is going on this issue.

President Obama: ...We've invested heavily in clean energy research. We believe very strongly that we've improved efficiencies and a whole step range of steps that we can meet and the commitments that we made in Copenhagen and Cancun. And as we move forward over the next several years, my hope is, is that the United States, as one of several countries with a big carbon footprint, can find further ways to reduce our carbon emissions. I 
think that's good for the world. I actually think, over the long term, it's good for our economies as well, because it's my strong belief that industries, utilities, individual consumers -- we're all going to have to adapt how we use energy and how we think about carbon.

$(16 / 11 / 2011)$

In example (16), the journalist directs the question to President Obama personally as he addresses him by referential you. Thus, an author-based answer is required. However, President Obama provides a principal-based answer, saying "we've invested heavily in clean energy research...emissions." Then, Obama employs a pronominal shift to indicate a change in footing from principal we to author I when he says "I think it's good...as well" to provide his opinion. He then changes footing once more from author to principal when he says"...we're all going to have...carbon" as he wishes to talk about the future acts that need to be taken to deal with the issue of energy. Obama does not answer the journalist's question in terms of his personal view of the matter as president of the United States. Rather, he answers using the principal-based we to refer to his administration as a whole. In other words, Obama answers in his institutional identity rather than his personal individual identity.

\section{Example (17)}

Question: Madame Secretary, the issue of the detainees at Guantanamo Bay has been some - has been a source of worldwide anger and frustration. You may have noticed here there were some small protests and at your next stop, in Auckland, there's a group of students who have offered a \$5,000 reward for anyone who can successfully perform a citizen's arrest on you for violations of the Geneva Convention. I'm wondering (a), if you're aware of this and what you make of it; and, more importantly (b), how are the plans going to close down Guantanamo? Can you commit, can the 
Administration commit to closing it down by the time President Bush leaves office?

Secretary Rice: Well, first of all, protest is a part of democratic society, and student protests are particularly a long-honored tradition in democratic society. And I can only say that the United States has done everything that it can to end this war on terror, to live up to our international and our national laws and obligations. Guantanamo is a detention center that, as the President has said, we would very much like to close. The problem, of course, is that there are dangerous people there who cannot be returned and put among innocent populations. We are hopeful that there will be the beginnings of the bringing to justice, the military tribunals for those people who are there. But let's not forget that a lot of innocent people have died at the hands of terrorists. And we must do everything that we can within our obligations legally and in terms of our treaty obligations to prevent that from ever happening again.

$(25 / 7 / 2008)$

In example (17), former U.S. Secretary of State, Condoleezza Rice, is asked two questions, the first of which requires an author-based reply. The second question, which is "Can you commit, can the Administration commit...?", requires a principal-based answer as reflected in the journalist's use of vague you which is then clarified by adding the word "Administration" to indicate that Rice needs to answer in her institutional identity as a representative of the U.S. administration. Condoleezza Rice complies and employs a pronominal shift from $I$ to we to change footing and shed light on the future hopes of the administration concerning the Guantanamo issue saying, "Guantanamo is a detention center that, as the President has said, we would very much like to close... We are hopeful that there will be the beginnings of the bringing to justice..."

Examples (18) and (19) demonstrate the shift from author $I$ to principal we to talk about past actions. 


\section{Example (18)}

Question: Dr. Rice, Western Australia is a state with significant uranium reserves. Has your agreements with India and Australia's role and what part we could play come up in your talks? Do you think there's a role for us there?

Minister Smith: Well, there are two separate issues. First is the export of Australian uranium. The government has a longstanding party policy position which is we don't export uranium to a country that is not a party to the Nuclear Nonproliferation Treaty. And I've made that clear to Indian officials and the Indian Government pretty much from day one of the new Australian Government's term in office. The India-U.S. nuclear civil arrangement is a separate matter, and a matter, indeed, that my memory is, Secretary, that when we first met in Washington, we discussed it there, as we have regularly...

$(25 / 7 / 2008)$

In this example, although the journalist directs the question to Condoleezza Rice as indicated by addressing her by title and last name "Dr. Rice", former Australian Foreign Minister, Stephen Smith, based on Rice's request to speak of the Australian position, also provides an answer to the question about whether Australia's possible role was brought up in the U.S.-Indian talks, given that "Western Australia is a state with significant uranium reserves." Stephen Smith answers on a principal-based footing using we by stating the stance of the Australian government on the export of Australian uranium saying, "...we don't...Treaty." He then changes footing by employing a pronoun shift to $I$, thereby adopting an author position to state that he clarified Australia's position on the matter to Indian officials and to the Indian government. He then directs his talk to Condoleezza Rice as he addresses her by her institutional role "Secretary", and shifts from $I$ to we to refer to past 
actions taken by Rice and himself concerning the US-Indian nuclear civil arrangement.

\section{Example (19)}

Question: And also on the matter of peacekeeping, what should NATO's future role in peacekeeping be? Especially if there is a peace in the Middle East, would you recommend that NATO forces serve in a peacekeeping operation there?

Madeleine Albright: The issue generally of peacekeeping, and let me just say this - this is something with which $\mathbf{I}$ had some previous experience - I think that it is important to try to find the right organization and right tool for peacekeeping. And one of the aspects that we talked about was how various organizations partner together on peacekeeping operations. We did leave open the possibility that - if the parties were interested and if there were a peace to keep in the Middle East - that this was a potential possibility.

\section{$(17 / 5 / 2010)$}

In example (19), the question about NATO's future role in peacekeeping and about whether NATO forces can serve in a peacekeeping operation in the Middle East is directed to both Anders Fogh Rasmussen, NATO Secretary General, and Madeleine Albright, Chair of the Group of Experts on NATO's New Strategic Concept, as seen in the use of vague you and in not asking one of them specifically to provide an answer. Albright answers the journalist's question. She starts her answer by giving her opinion on peacekeeping saying "I think it is important to try to find the right organization and right tool for peacekeeping." She then shifts footing from author to principal to talk about the past actions taken by NATO on the issue in question.

Female politicians, unlike their male counterparts, change footing by shifting from $I$ to we to talk about achievements made by their countries and also to express the convictions held by these 
countries. These two reasons are shown in examples (20) and (21), respectively.

\section{Example (20)}

Question: Thank you, Mr. President. Thank you, Prime Minister Gillard. I wanted to double back to the topic of China. It seems there's a bit of a schizophrenic aspect to this week of summitry in the Asian Pacific, where China is participating from Hawaii to Indonesia, but then you have all the rest of you who are talking about, on one hand, a trade bloc that excludes China, and now this - and an increased military presence for the United States, which is symbolized most by this agreement the two of you have made for a permanent U.S. presence in Australia. What is it everyone fears so much from China? And isn't there some risk that you would increase tensions in a way that would take some of the -- China might take some of the very actions you fear?

Prime Minister Gillard: ... both of our nations deeply engaged with China as it rises and we want to see China rise into the global rules-based order. That's our aspiration. I understand it to be the aspiration of the United States. It's something that we pursue bilaterally with China. It's something that we pursue multilaterally in the various forums that we work in.

$(16 / 11 / 2011)$

In this example, the journalist asks about the reason the U.S. and Australia fear China as reflected in a "trade bloc that excludes China" and an increased military presence for America in Australia. In answering the question, Julia Gillard, former Australian Prime Minister, speaks as a principal when she says, "...we want to see China rise into the global rules-based order." Then she shifts from principal we to author I to say what she knows to be the aspiration of the United States concerning China ("I understand it...China). She then changes footing again from author to principal to speak of the achievements made by the United States 
and Australia to meet this aspiration ("It's something that we pursue multilaterally in the various forums that we work in").

\section{Example (21)}

Question: Dr. Rice, Western Australia is a state with significant uranium reserves. Has your agreements or talks with India and Australia's role and what part we could play come up in your talks? Do you think there's a role for us there?

Secretary Rice: Well, we have talked about the U.S.-India Civil Nuclear Deal. I'll ask Stephen to speak to the Australian position, but the -- we've made very clear that we believe that this is an agreement that serves the interests of the U.S.-Indian strategic relationship.

$$
(25 / 7 / 2008)
$$

In example (21), former U.S. Secretary of State, Condoleezza Rice, is asked about whether the role Australia can play in the U.S.-India civil nuclear arrangement come up in the talks between U.S. and India. Rice first answers on a principalbased footing when she says," ...we have talked about the US-India Civil Nuclear Deal. She then shifts to I to say that she will ask former Australian Foreign Minister, Stephen Smith, to talk about Australia's position on this issue. Rice then changes footing by shifting from author to principal to explain the conviction of the U.S. administration that the agreement between U.S. and India "serves the interests of the U.S.-Indian strategic relationship."

\subsubsection{Male-Female Use of Pronominal Shifts from we to I}

In the question-answer sessions, male and female politicians change footing by employing a pronominal shift from the first person plural we to the first person singular pronoun $I$ for four common reasons. These are: to express an opinion, clarify a stance, shed light on future acts or hopes, and make personal comments. 
In examples (22) and (23), male and female politicians shift from we to $I$ to express their opinions.

\section{Example (22)}

Question: Thank you, Mr. President. Chancellor Merkel said this week that Europe is in its toughest hour since World War II. Markets are now showing some anxiety about the possibility of instability spreading to France as well. Are you worried that the steps European leaders are taking are too incremental so far? Do you think something bolder or a more difficult set of decisions need to be taken to fully (inaudible) that crisis?

President Obama: ...We have consulted very closely with our European friends. I think that there is a genuine desire, on the part of leaders like President Sarkozy and Chancellor Merkel, to solve this crisis.

In this example, President Obama answers a question about the steps or decisions that need to be made to deal with the problem of instability of European markets by adopting a principal-anchored footing using we saying, "We have consulted very closely with our European friends." $\mathrm{He}$ then changes footing from the principalbased to author-based position using $I$ to express his opinion on this matter saying, "I think...crisis."

\section{Example (23)}

Question: Q Dr. Rice, if we could just lighten up as we wrap up here. President Bush is coming to the end of his term. Over the years, satirists have had a bit of fun with him. In Australia, he may be seen as a larrikin. What's he like as a boss?

Secretary Rice: ... he's outraged by certain things. And I'll tell you something that he finds very difficult to deal with. He finds it difficult when he sees people who live in tyranny. I know that that's 
considered somewhat old fashioned, to believe that no man, woman or child should have to live in tyranny, but as somebody who himself is free, he's offended by the continuance of dictatorships in this world...I know that there's sometimes a misreading of that to suggest that we're somehow naive, that on our watch, all dictatorships were going to go away, we were going to end tyranny for all time..., I'm a firm believer that it's all right to be a little bit on the side of too optimistic and too idealistic, rather than too cynical and too pessimistic about human beings and what they can achieve. Because if you look back over history...in one night the hammer and sickle came down, the tricolor went up; did we think any of that possible? Well, those things that seemed impossible now seem, in retrospect, inevitable. So I think the President is someone who, if he has to err, he'll err on the side of idealism and optimism.

$(25 / 7 / 2008)$

Condoleezza Rice here is required to say how President Bush is like as a boss. In her response, Rice employs an authorbased footing $I$ when she talks about the policy of former U.S. President, George Bush, by saying that certain things outrage him, that he finds it difficult to see people living in tyranny, and that "he's offended by the continuance of dictatorships in this world." She then shifts from author-anchored I to principal-anchored we to refer to the U.S. administration in "I know...naïve...we were going..." Rice then shifts to $I$ to express her opinion on ending tyranny saying, "I'm a firm believer...achieve." She then says that history says that "in one night the hammer and sickle came down, the tricolor went up..." Here Rice shifts again from author $I$ to principal we to show that tyranny can quickly come to an end. To express her opinion once more, she employs another pronominal shift from we to I in "So I think...optimism" to relate what she said to the character of former President, George Bush. 
Employing a pronominal shift from we to $I$ to clarify a stance by male and female politicians is shown in examples (24) and (25).

\section{Example (24)}

Question: Two questions if I might for both of you. First of all, on missile defense, we understood that the November Lisbon Summit would be deciding whether or not missile defense should become a NATO mission. I read in the report that it has become for NATO an essential military mission. So can you just clarify where exactly are we on the missile defense debate? Is it now decided that that's a NATO mission or do we wait for November till that one?

Anders Fogh Rasmussen: On missile defense, we have not yet decided whether missile defense can or should be considered an Alliance mission. This is for the summit in November to decide.

This is an independent report from an independent group. This group considers, apparently, missile defense an important Alliance mission. I could add to this that, personally, I fully agree with the group of experts.

$(17 / 5 / 2010)$

In this example, the journalist inquires about whether it has been decided that missile defense is a NATO mission. NATO Secretary General, Anders Fogh Rasmussen, first adopts a principal-anchored footing using we to answer the question saying, "...we have not...mission." Then he changes footing by shifting from principal we to author $I$ to express his stance on the issue saying, "I could add to this that, personally, I fully agree with the group of experts."

\section{Example (25)}

Question: Madam Secretary, you mentioned Syria and just before we came up here, Ahmad Fawzi, the spokesperson for Kofi Annan, said that they have credible reports that when the monitors go into places and then leave, that the people, the civilians who have ro 
approached them, talked with them, or met with them, are having very serious problems, that they're being harassed, arrested, and possibly even killed. Do you have any indication from U.S. sources that this is the case? If this is the case, what can be done?

Secretary Clinton: ...We supported Kofi Annan's plan. No one stands to gain if the plan fails. In fact, the only sources - or the only potential gainers would be the enemies of peace and change. So the bulk of the responsibility rests with Assad and with his supporters and his military to demonstrate a commitment to the Annan plan by silencing the guns, making sure that they're on a path toward the six points that Kofi Annan has set forth, which the Syrians claim they agree with, including a political transition. So we have continued consulting closely with our friends and allies in the region and beyond about what additional steps could be taken, but we would like to see Kofi Annan's plan succeed... So I strongly condemn the reports that we heard earlier today and want to be kept totally informed about what is happening inside Syria, because the entire world is watching.

$(24 / 4 / 2012)$

In this example, Hillary Clinton, who is addressed by referential you, answers the journalist's question first by using the first person plural pronoun we to talk about the acts taken by the U.S. administration regarding Syria saying, "...We supported Kofi Annan's plan...we have continued consulting closely with our friends and allies...but we would like to see Kofi Annan's plan succeed." She then shifts from we to I to express her own stance on the issue of Syria saying, "So I strongly condemn the reports..."

Shifting from we to $I$ to shed light on future acts or hopes by male and female politicians is demonstrated in examples (26) and (27). 


\section{Example (26)}

Question: You posted, sorry, word for bloggers, for Internet users. Are there any ideas from the people from the Internet concerning the new concept of NATO?

Anders Fogh Rasmussen: I think that several of the ideas presented by bloggers and other participants from the broader public have been represented in the groups' report, maybe not exactly in the form in which they were presented on the net... We have really enjoyed that so many people have contributed to our work. And I hope that they will continue discussion as we approach the summit in November.

$$
(17 / 5 / 2010)
$$

The journalist here asks Anders Fogh Rasmussen whether he got ideas from Internet users about the concept of NATO. Adopting an author-anchored footing using $I$, Rasmussen says that the ideas given by bloggers are included in the group's report. He then shifts to a principal-based footing by employing we to say that the group of experts who prepared the report on the New Strategic Concept of NATO were happy with the contribution made by the people to their work. Rasmussen shifts once more to $I$ to highlight a personal hope for the future saying, "And I hope...November."

\section{Example (27)}

Question: Dr. Rice, this morning a student asked you if you were keen on becoming President. Have you ruled it out completely? Secretary Rice: .... Look, the United States is an extraordinary country. It's a country that I love very, very deeply. It's a country that I've been proud to represent. It's a country that sometimes has to take difficult decisions, and we're not always popular in taking those decisions. But $\mathbf{I}$ hope that people know that we've always taken them in hopes of defending freedom, defending values, and making the world a better place.

$(25 / 7 / 2008)$ 
Asked if she has ruled out the idea of becoming President, former U.S. Secretary of State, Condoleezza Rice, provides an author-anchored using $I$ to show her feelings towards her country. Then she shifts footing from author to principal to talk as a representative of U.S. administration saying, "... we're not always popular in taking those decisions." Rice then employs another shift from principal to author to say that she hopes people would know that these decisions are taken "in hopes of defending freedom, defending values, and making the world a better place."

As shown in examples (28) and (29), male and female politicians change footing from we to $I$ to make personal comments.

\section{Example (28)}

Question: And, Mr. President, you also mentioned in your remarks that Afghanistan is not an easy mission. In the past few months there have been three cases for Australia where our troops have been shot at by the Afghan soldiers who have been training and, sadly, four of our soldiers have died and many others have been injured. Australian public opinion is strongly against our involvement continuing. You've outlined the -- just then, the drawdown. What can you say to the Australian people who don't want to wait, who want to leave immediately?

President Obama: ...What we have established is a transition process that allows Afghans to build up their capacity and take on a greater security role over the next two years. But it's important that we do it right... But what I recognized was that if we weren't thoughtful about how we proceed, then the enormous sacrifices that had been made by our men and women in the previous years might be for naught. And what I'd say to the Australian people at this point is, given the enormous investment that's been made and the signs that we can, in fact, leave behind a country that's not perfect, but one that is more stable, more secure, and does not provide safe 
haven for terrorists, it's appropriate for us to finish the job and do it right.

In example (28), President Obama is asked personally, using referential you, to say something to the Australians who want Australian troops to withdraw immediately from Afghanistan. In his answer, Obama adopts a principal-based footing using the first person plural pronoun we to talk about the acts taken by Australia and the U.S. concerning Afghanistan saying, "what we ...right." Then he shifts to I to say that he realized that "if we weren't thoughtful about how we proceed, then the enormous sacrifices that had been made by our men and women in the previous years might be for naught." Here Obama shifts from author I to principal we again to talk about the Australian and U.S. side. To make a personal comment to the Australian people, Obama changes footing by shifting from principal to author as realized through a pronominal shift from we to I saying "And what I'd say to the Australian people...right."

\section{Example (29)}

Question: Madame Secretary, you've been telling us -- Madame Secretary, you've been telling us about progress made privately between the Israelis and Palestinians towards a draft peace agreement. Next week, there will be the trilateral in Washington. Will you be able, finally, to give some public details of the progress they've been making, and will you be applying pressure to (inaudible) both sides into that deal you really want before you leave office - or before President Bush leaves office?

Secretary Rice: Well, the first answer is no. We won't be providing details of what goes on in the trilateral. They are -- the Israelis and the Palestinians have their first serious peace process in seven years, and they are discussing very sensitive and difficult issues. I would remind that the most effective negotiations they 
probably ever had were Oslo, and no one even knew they were negotiating...

In example (29), the journalist uses vague you to ask Condoleezza Rice about the possibility of giving details concerning the progress made "between the Israelis and Palestinians towards a draft peace agreement." So, Rice answers on a principal-based footing saying, "We won't be providing details..." Then she shifts from principal we to author $I$ to make a personal comment concerning the Israeli-Palestinian negotiations saying, "I would remind...negotiating."

Unlike female politicians, male politicians adopt a change in footing realized through a pronominal shift from we to $I$ to talk about past actions that they carried out themselves. This is shown in example (30).

\section{$\underline{\text { Example (30) }}$}

Question: Australia has pulled its combat forces out of Iraq. Secretary Rice, would you like to see more of those forces move to Afghanistan, where there's a great need for more forces?

Minister Smith: ...We are very grateful for the role that our forces play in Afghanistan. And at Swanbourne Barracks, I said to some of the regiment there that they do really need to understand that the work they do in difficult and dangerous circumstances is very genuinely appreciated by our friends and allies. I also made the point that...that the work they do in conjunction with our friends and allies...helps give Foreign Ministers of Australia street cred when they walk in the door.

$(25 / 7 / 2008)$

In this example, former Australian Foreign Minister, Stephen Smith, gives some remarks on the issue of the Australian troops in Afghanistan. He first uses we to refer to the Australian 
government when he says "We are very grateful for the role that our forces play in Afghanistan." Here he expresses how the government feels about the role of Australian forces in Afghanistan. Smith then changes footing by shifting from we to $I$ in "...I said to some... I also made the point that..." By changing from principal we to author $I$, Smith indicates that he is speaking in his individual identity and not his institutional one. The shift from we to $I$ aims at shedding light on past actions that Stephen Smith carried out himself.

\section{Results and Discussion}

The total number of changes in footing realized through shifts between the first person singular pronoun $I$ and the first person plural pronoun we in the analyzed joint political press conferences is $174,62(36 \%)$ of which occur in the speech sessions and $112(64 \%)$ in the question-answer sessions. Table (1) shows the number of pronominal shifts between $I$ and we by male and female politicians in the analyzed press conferences.

Table (1): Number of Pronominal Shifts between $I$ and We by Male and Female Politicians in the Analyzed Press Conferences

\begin{tabular}{|c|c|c|c|}
\hline & $\begin{array}{c}\text { Speech } \\
\text { Sessions }\end{array}$ & $\begin{array}{c}\text { Question- } \\
\text { Answer } \\
\text { Sessions }\end{array}$ & $\begin{array}{c}\text { Total in the } \\
\text { Analyzed Press } \\
\text { Conferences }\end{array}$ \\
\hline Male Politicians & $31(50 \%)$ & $60(53.5 \%)$ & $91(52 \%)$ \\
\hline $\begin{array}{c}\text { Female } \\
\text { Politicians }\end{array}$ & $31(50 \%)$ & $52(46.5 \%)$ & $83(48 \%)$ \\
\hline Total & $62(100 \%)$ & $112(100 \%)$ & $174(100 \%)$ \\
\hline
\end{tabular}

Table (1) shows that in the speech sessions, male and female politicians shift between $I$ and we the same number of times. Male politicians alternate between these two pronouns 31 times $(50 \%$ of the total of their occurrence in the speech sessions which is 62) and so do female politicians. Shifting between $I$ and we the same 
number of times by male and female politicians in the speech sessions may be because in these sessions the host politician reflects on his/her meeting with the guest politician. Thus, it seems that in these sessions both male and female politicians are equally concerned with showing that their meeting was successful by striking a balance between speaking in their individual and institutional identities. In the question-answer sessions, the number of shifts between $I$ and we made by male politicians outnumbers those made by female politicians; male politicians shift between $I$ and we 60 times $(53.5 \%$ of the total number of their occurrence in the question-answer sessions which is 112) while female politicians make these shifts 52 times $(46.5 \%$ of the total number of their occurrence in the question-answer sessions). This may be attributed to the journalists' questions as some of these questions may drive male politicians to shift between these two pronouns more than female politicians for different reasons like wanting to avoid giving the required answers or evading responsibility. Table (1) also shows that the total number of shifts made by male politicians in the speech sessions and question-answer sessions is 91 (52\% of the total number of shifts between $I$ and $W e$ in the analyzed data which is 174), while the total number of these shifts by female politicians is 83 (48\% of the total number of shifts between the first two person pronouns under analysis).

Table (2) demonstrates a detailed account of the number of shifts made by male and female politicians between the first person singular and first person plural pronouns in the speech sessions and question-answer sessions. 
Table (2): Frequency of occurrence of Pronominal Shifts between $I$ and We by Male and Female Politicians in the Speech Sessions and QuestionAnswer Sessions

\begin{tabular}{|c|c|c|c|c|c|c|}
\hline \multirow[t]{2}{*}{$\begin{array}{c}\text { Pronominal } \\
\text { Shifts }\end{array}$} & \multicolumn{2}{|c|}{ Speech Sessions } & \multirow{2}{*}{$\begin{array}{l}\text { Total in } \\
\text { Speech } \\
\text { Sessions }\end{array}$} & \multicolumn{2}{|c|}{$\begin{array}{c}\text { Question-Answer } \\
\text { Sessions }\end{array}$} & \multirow{2}{*}{$\begin{array}{c}\text { Total in } \\
\text { Question- } \\
\text { Answer } \\
\text { Sessions }\end{array}$} \\
\hline & $\begin{array}{c}\text { Male } \\
\text { Politicians }\end{array}$ & $\begin{array}{c}\text { Female } \\
\text { Politicians }\end{array}$ & & $\begin{array}{c}\text { Male } \\
\text { Politicians }\end{array}$ & $\begin{array}{l}\text { Female } \\
\text { Politicians }\end{array}$ & \\
\hline $\mathrm{I} \rightarrow \mathrm{We}$ & $16(50 \%)$ & $16(50 \%)$ & $32(100 \%)$ & $31(53.5 \%)$ & $27(46.5 \%)$ & $58(100 \%)$ \\
\hline $\mathrm{We} \rightarrow \mathrm{I}$ & $15(50 \%)$ & $15(50 \%)$ & $30(100 \%)$ & $29(54 \%)$ & $25(46 \%)$ & $54(100 \%)$ \\
\hline
\end{tabular}

Table (2) shows that in the speech sessions male and female politicians shift from $I$ to we 16 times each $(50 \%$ of the total number of occurrence of this pronominal shift in the speech sessions which is 32) and from we to I 15 times each (50\% of the total number of occurrence of this pronominal shift in the speech sessions which is 32). That male and female politicians shift between the first person singular and first person plural pronouns the same number of times in the speech sessions indicates that in these sessions, both male and female politicians give equal importance to expressing their own ideologies and personal views as well as those of the governments or parties they represent. In the question-answer sessions, male politicians shift from $I$ to we and from we to $I$ more than female politicians. Indeed, male politicians shift from $I$ to we 31 times (53.5\% of the total number of occurrence of this pronominal shift in the question-answer sessions which is 58), while female politicians make this shift 27 times (46.5\% of the total number of occurrence of this pronominal shift in the questionanswer sessions which is 58). Whereas male politicians shift from we to I 29 times (54\% of the total number of occurrence of this pronominal shift in the question-answer sessions which is 54), female politicians make this shift 25 times ( $46 \%$ of the total number of occurrence of this pronominal shift in the question-answer sessions which is 54). The minor difference in the frequency of 
occurrence of these pronominal shifts by male and female politicians in the question-answer sessions may indicate that in the political arena, males and females are almost equally concerned with speaking in their individual and institutional identities when answering journalists' questions.

Table (2) also shows that both male and female politicians shift from $I$ to we more than they do from we to $I$. Male politicians shift $I$ to we 31 times (53.5\%) and from we to $I 29$ times (54\%). Female politicians shift from $I$ to we 27 times (46.5\%) and from we to $I 25$ times (46\%). The subtle difference indicates that sometimes, depending on the kind of questions they are asked in the questionanswer sessions, the answers they are required to give, and the answers that they actually give, male and female politicians prefer to construct their identities as representatives of their countries or of particular parties to communicating their individual identities.

Since the data reveals that male and female politicians rely mostly on the pronominal shift between the first person singular and first person plural pronouns, it is deemed important to investigate the purposes for shifting between $I$ and we to change footing. Tables (3) and (4) demonstrate the reasons for making pronominal shifts between $I$ and we and the frequency of occurrence of each reason in the speech sessions and questions-answer sessions, respectively. 
Table (3): Reasons and Frequency of Occurrence of Shifts between $I$ and $W e$ in the Speech Sessions

\begin{tabular}{|c|l|c|l|c|}
\hline \multirow{3}{*}{$\begin{array}{c}\text { Pronominal } \\
\text { Shifts }\end{array}$} & \multicolumn{3}{|l|}{ Male Politicians } & \multicolumn{2}{|l|}{ Female Politicians } \\
\cline { 2 - 5 } & $\begin{array}{l}\text { Reasons for } \\
\text { Occurrence }\end{array}$ & $\begin{array}{c}\text { Frequency of } \\
\text { Occurrence }\end{array}$ & $\begin{array}{c}\text { Reasons for } \\
\text { Occurrence }\end{array}$ & $\begin{array}{c}\text { Frequency of } \\
\text { Occurrence }\end{array}$ \\
\hline \multirow{4}{*}{$\mathbf{I} \rightarrow$ We } & $\begin{array}{l}\text { Future } \\
\text { acts/hopes }\end{array}$ & $5(31 \%)$ & Future acts/hopes & $5(31 \%)$ \\
\cline { 2 - 5 } & Past Actions & $4(25 \%)$ & Past Actions & $4(25 \%)$ \\
\cline { 2 - 5 } & Achievements & $4(25 \%)$ & Achievements & $4(25 \%)$ \\
\cline { 2 - 5 } & Positive Acts & $3(19 \%)$ & Positive Acts & $3(19 \%)$ \\
\hline \multirow{2}{*}{ Total } & & $16(100 \%)$ & & $16(100 \%)$ \\
\hline \multirow{3}{*}{ We $\rightarrow \mathbf{I}$} & Opinions & $11(73 \%)$ & Opinions & $5(33 \%)$ \\
\cline { 2 - 5 } & Feelings & $4(27 \%)$ & Feelings & $7(47 \%)$ \\
\cline { 3 - 5 } & & & $\begin{array}{l}\text { Personal } \\
\text { Comments }\end{array}$ & $3(20 \%)$ \\
\hline \hline Total & & $15(100 \%)$ & & $15(100 \%)$ \\
\hline
\end{tabular}

Table (3) shows that male and female politicians shift from $I$ to we in the speech sessions for four reasons, namely to shed light on future acts or hopes, talk about past actions taken by their governments, parties or groups, indicate achievements, and refer to positive acts taken by their governments or countries. Shifting from I to we to talk about future acts or hopes is used 5 times (31\%) by male as well as female politicians. Both male and female politicians also make this shift to talk about past actions (4 occurrences, $25 \%$ ), achievements (4 occurrences, 25\%), and positive acts (3 occurrences, 19\%). The fact that the reasons for shifting from $I$ to we in the speech sessions are common between male and female politicians and occur the same number of times indicates that both of them are equally concerned with talking about future acts or hopes, past actions, achievements, and positive acts. Shedding light on future acts or hopes more frequently in the speech sessions than talking about past actions, achievements, and positive acts shows that in these sessions, talking about the future is of prime importance and concern to both male and female politicians as they want to assure their audience that agreements have been made 
concerning carrying out certain future acts. They also aim at expressing what they hope for concerning certain issues. Moreover, since in the speech sessions politicians show that their meeting was successful and that they have similar views on various, and sometimes controversial, topics, it is deemed necessary and crucial to talk more about the future and less about the past.

Table (3) also shows that both male and female politicians shift from we to $I$ to state opinions and express feelings. The frequency of occurrence of expressing opinions and feelings when shifting from we to $I$ in the speech sessions is an indicator of the inclination of the speakers. While male politicians tend to shift from we to $I$ to state their opinions (11 occurrences, $73 \%$ ) more than to express their feelings ( 4 occurrences, $27 \%$ ), female politicians make this pronominal shift to express their feelings ( 7 occurrences, $47 \%$ ) more than to state their opinions (5 occurrences, 33\%). This is in line with previous research which has found that the focus of male speech is on information. Thus, males are more inclined to give their opinions, while females are more expressive of their feelings and emotions (Holmes, 1998; Mehl \& Pennebaker, 2003; Newman, Groom, Handelman, \& Pennebaker, 2008; Thomson \& Murachver, 2001). Unlike male politicians, female politicians also shift from we to $I$ to make personal comments. Shifting for this reason occurs 3 times only (20\%). This is probably because in the speech sessions, politicians, whether males or females, are expected to focus on showing that their meeting was successful rather than commenting on issues that have been discussed. Thus, when male and female politicians wish to express their personal feelings and opinions and when female politicians wish to make personal comments, they shift from we to $I$ since this shift reflects a change in footing which speakers employ to talk in their individual identities rather than as representatives of their governments. 
Table (4): Reasons and Frequency of Occurrence of Shifts between $I$ and $W e$ in the Question-Answer Sessions

\begin{tabular}{|c|c|c|c|c|}
\hline \multirow{2}{*}{$\begin{array}{c}\text { Pronominal } \\
\text { Shifts }\end{array}$} & \multicolumn{2}{|c|}{ Male Politicians } & \multicolumn{2}{|c|}{ Female Politicians } \\
\hline & $\begin{array}{l}\text { Reasons for } \\
\text { Occurrence }\end{array}$ & $\begin{array}{l}\text { Frequency of } \\
\text { Occurrence }\end{array}$ & $\begin{array}{l}\text { Reasons for } \\
\text { Occurrence }\end{array}$ & $\begin{array}{c}\text { Frequency of } \\
\text { Occurrence }\end{array}$ \\
\hline \multirow{5}{*}{$\mathbf{I} \rightarrow \mathbf{W e}$} & Stance & $11(35.5 \%)$ & Stance & $4(15 \%)$ \\
\hline & Future acts/hopes & $11(35.5 \%)$ & Future acts/hopes & $5(18.5 \%)$ \\
\hline & \multirow[t]{3}{*}{ Past Actions } & \multirow[t]{3}{*}{$9(29 \%)$} & Past Actions & $10(37 \%)$ \\
\hline & & & Achievements & $5(18.5 \%)$ \\
\hline & & & Convictions & $3(11 \%)$ \\
\hline Total & & $31(100 \%)$ & & $27(100 \%)$ \\
\hline \multirow{5}{*}{$\mathbf{W e} \rightarrow \mathbf{I}$} & Opinion & $10(34 \%)$ & Opinion & $14(56 \%)$ \\
\hline & Stance & $6(21 \%)$ & Stance & $5(20 \%)$ \\
\hline & Future acts/hopes & $4(14 \%)$ & Future acts/hopes & $3(12 \%)$ \\
\hline & $\begin{array}{c}\text { Personal } \\
\text { Statements }\end{array}$ & $4(14 \%)$ & Personal Statements & $3(12 \%)$ \\
\hline & Past Actions & $5(17 \%)$ & $\begin{array}{l}-- \\
-\end{array}$ & --- \\
\hline Total & & $29(100 \%)$ & & $25(100 \%)$ \\
\hline
\end{tabular}

Table (4) shows that in the question-answer sessions, male and female politicians shift from $I$ to $w e$ for three common reasons, namely to express a stance, shed light on future acts or hopes, and talk about past actions. The frequency of occurrence of these reasons in the speech of male and female politicians differs markedly. While male politicians express a stance 11 times (35.5\%), shed light on future acts or hopes 11 times (35.5\%), and talk about past actions 9 times (29\%), female politicians express a stance 4 times (15\%), shed light on future acts or hopes 5 times (18.5\%), and talk about past actions 10 times (37\%). The difference in the frequency of occurrence can be explained in light of the fact that by shifting from I to we politicians, whether males or females, talk in their institutional identities. Therefore, by expressing a stance and talking about future acts or hopes more than female politicians, male politicians may want to show a strong desire to 
clarify where their governments stand with respect to various controversial political issues. Female politicians, on the other hand, talk about past actions more than male politicians. They are probably more concerned with explaining the past doings of their governments as the outcomes of these doings can have considerable influence on the present and future decisions taken by the governments. Female politicians shift from $I$ to we for two more reasons that are not found in the speech of male politicians in the question-answer sessions. These are: to talk about achievements (5 occurrences, $18.5 \%$ ) and express certain convictions (3 occurrences, $11 \%$ ). The reason for this could be that female politicians employ this pronominal shift to talk about achievements and convictions in order to avoid providing the required answers to questions that may need certain answers that they cannot give or do not want to give. This supports the view that females, whether politicians or nonpoliticians, tend to be indirect in their speech (Lakoff, 2003: 162).

Table (4) also shows that male and female politicians shift from we to $I$ in the question-answer sessions for four common reasons, the most frequently occurring of which is the desire to express an opinion. Shifting for this reason occurs 10 times (34\%) in the speech of male politicians and 14 times (56\%) in that of female politicians. Thus, in the question-answer sessions, when female politicians speak in their individual identities, they tend to express their own personal opinions more than male politicians. This may be attributed to the journalists' questions as they might tackle thorny issues and thus female politicians feel more compelled than their male counterparts to give their opinions on these contentious issues. The second most frequently occurring reason is the desire to explain a stance. This reason occurs 6 times $(21 \%)$ in the speech of male politicians and 5 times $(20 \%)$ in the speech of female politicians. The other two reasons are: shedding light on future acts or hopes and making personal comments. Each of these two reasons occurs 4 times (14\%) in the speech of male politicians 
and 3 times (12\%) in that of female politicians. The last three reasons occur more in the speech of male politicians than in that of female ones probably because the issues that journalists ask about drive male politicians not only to answer in their individual identities but also to hammer certain messages home by expressing a stance, talking about future acts or hopes, and making personal statements. Unlike female politicians, male politicians also employ a pronominal shift from we to $I$ to talk about some past actions that they did (5 occurrences, 17\%). They might want to present themselves in a positive light possibly to achieve certain political goals. Shifting from we to $I$ for this reason is absent from the speech of female politicians since they might not be interested in talking about their own deeds or achievements in this context.

\section{Conclusion}

The present study has attempted to examine the similarities and/or differences between male and female politicians in changing footing by shifting between the first person singular pronoun and the first person plural pronoun in joint political press conferences as well as the reasons for doing so. In this respect, Goffman's (1981) concepts of participation framework and footing have been used to analyze the data.

Results have shown that male and female politicians change footing using shifts between the first person pronouns in the analyzed data 174 times, 62 of which occur in the speech sessions and 112 in the questions-answer ones. It has also been found that male and female politicians are similar in that both of them change footing by adopting these pronominal shifts the same number of times in the speech sessions. The difference occurs in the questionanswer sessions as male politicians shift between the two pronouns in question more than female politicians. Indeed, male politicians change footing by alternating between $I$ and we 60 times (53.5\%) in the question-answer sessions, while female politicians change footing by shifting between these two pronouns 52 times $(46.5 \%)$ in 
the same sessions. Moreover, in the question-answer sessions, male and female politicians are similar in that both shift from $I$ to we more than they do from we to $I$. This reflects a common tendency between male and female politicians to emphasize their institutional identities more than their individual ones.

The reasons for shifting between $I$ and $w e$ and the frequency of occurrence of each reason in the speech sessions and questionanswer sessions highlight some similarities and differences between male and female politicians in the data under analysis. In the speech sessions, both male and female politicians shift from $I$ to we to shed light on future acts or hopes, talk about past actions, indicate achievements, and refer to positive acts carried out by their countries or governments. These reasons occur the same number of times in the speech of male and female politicians, thereby indicating a convergence in their ideologies when speaking in their institutional identities in these sessions. In the same sessions, stating personal opinions and expressing feelings are the two reasons for which both male and female politicians shift from we to $I$. However, whereas the former is more frequent in the speech of male politicians, the latter occurs more in the speech of female politicians. This emphasizes the view that the speech of females is more emotional than that of males. Unlike male politicians, female politicians also shift from we to $I$ in the speech sessions to make personal comments.

In the question-answer sessions, male and female politicians shift from $I$ to we for similar reasons. These are: to express a stance, talk about future acts or hopes, and talk about past actions. Nevertheless, male politicians focus more on expressing a stance and shedding light on future acts or hopes than on talking about past actions. Female politicians are primarily concerned with talking about past actions and less so with expressing a stance and shedding light on future acts or hopes. Unlike male politicians, female politicians also shift from $I$ to we in these sessions to talk about 
achievements and express certain convictions. Both male and female politicians shift from we to $I$ in the question-answer sessions for the same reasons, namely to express an opinion, explain a stance, talk about future acts or hopes, and make personal statements. Although expressing an opinion is the most frequent reason for shifting from we to $I$ in the speech of both male and female politicians, it occurs more frequently in the speech of female politicians than that of male politicians. Three reasons for shifting from we to $I$ in the question-answer sessions occur more in the speech of male politicians than that of female politicians. These are: to explain a stance, talk about future acts or hopes, and make personal statements. Unlike female politicians, male politicians shift from we to $I$ in the question-answer sessions to talk about past actions that they have carried out.

The use of the first person singular pronoun $I$ by male and female politicians indicates that they speak as individual politicians since they talk about certain issues from their individual perspective and give their own viewpoints. Using the first person plural pronoun we enables politicians to construct their identities as members of groups. Thus, politicians' use of $I$ represents the construction of their individual identities while the use of we reflects the construction of their institutional identities. Moreover, politicians' employment of a pronominal shift from $I$ to we and vice versa indicates that these pronouns are used in different footings and are thus used to construct different identities. Therefore, the alternation between $I$ and we reflects an alternation between politicians' individual and institutional identities.

In terms of participation framework, the use of $I$ represents adopting an author-based footing whereas we represents a principalanchored footing. Alternating between $I$ and we represents an alternation between author and principal. Whether politicians employ an author-based footing or a principal-based one, in both 
cases they are animators since they are the physical utterers of the words.

Future research can investigate pronominal shifts used by politicians from different countries or different ideological backgrounds to see how ideological differences are reflected in politicians' pronominal choices. Since the present study focuses only on the shifts between the first person pronouns in joint political press conferences, it would be interesting to study other pronominal shifts made by male and female politicians in other types of political discourse. Future research can further compare politicians' and non-politicians' use of personal pronouns to construct their identities and express their ideologies.

\section{Transcription Conventions}

... Omitted speech 


\section{References}

Adetunji, A. (2006). Inclusion and Exclusion in Political Discourse: Deixis in Olusegun Obasanjo's Speeches. Journal of Language and Linguistics, 5(2), 177-191.

Allen, W. (2006, July). Australian Political Discourse: Pronominal Choice in Campaign Speeches. Paper presented at the Annual Meeting of the Australian Linguistic Society, Brisbane, Australia. Retrieved from http://espace.library.uq.edu.au/eserv/UQ:12794/ALLEN_W _ALS2006.pdf

Banning, S.A., \& Billingsley, S. (2007). Journalist Aggressiveness in Joint Versus Solo Presidential Press Conferences. Mass Communication \& Society, 10(4), 461-478.

Bazzanella, C. (2002). The Significance of Context in Comprehension: The 'we case'. Foundations of Science, 7(3), 239-254.

Beard, A. (2000). Language of Politics. London: Routledge.

Bhatia, A. (2006). Critical Discourse Analysis of Political Press Conferences. Discourse \& Politics, 17(2), 173-203.

Biber, D., Conrad, S., \& Reppen, R. (1998). Corpus Linguistics: Investigating Language Structure and Use. Cambridge: Cambridge University Press.

Bramely, N.R. (2001). Pronouns of Politics: The use of Pronouns in the Construction of 'Self' and 'Other' in Political Interviews (Doctoral dissertation, Australian National University). Retrieved from

http://digitalcollections.anu.edu.au/bitstream/1885/46225/0 6/ 02whole.pdf

Brown, R., \& Gilman, AA. (1960). The Pronouns of Power and Solidarity. In T.A. Sebeok (Ed.), Style in Language (pp. 253-276). Cambridge: MIT Press.

Bull, P., \& Fetzer, A. (2006). Who are we and who are you? The Strategic Use of Forms of Address in Political Interviews. Text \& Talk, 26(1), 3-37.

Chen, L.-C., L. (2006). A Study of First-Person Pronouns in Chinese Political Discourse: A Study of Political Interviews, Political Speeches, and Political Debates. Proceedings of 
Hsing Kuo University of Management: Conference on English Language Studies (II). Tainan: Taiwan ELT Publishing Co., Ltd.

Cheng, M. (2002). The Standoff-What is Unsaid? A Pragmatic Analysis of the Conditional Marker "If". Discourse \& Society, 13(3), 309-317.

Chilton, P., \& Schäffner, C. (1997). Discourse and Politics. In Teun van Dijk (Ed.), Discourse as Social Interaction: Vol. 2. Discourse Studies: A Multidisciplinary Introduction (pp. 206-230). London: Sage.

Clayman, S. (1992). Footing in the Achievement of Neutrality: The Case of News-Interview Discourse. In Drew, P. \& J. Heritage (Eds.), Talk at Work: Interaction in Institutional Settings (pp. 163-198). New York: Cambridge University Press.

Clayman, S. (2006). Arenas of Interaction in the New Media Era. In M. Ekström, A. Kroon, \& M. Nylund (Eds.), News from the Interview Society (pp. 239-264). Göteborg: Nordicom.

Clayman, S., Elliott, M., Heritage, J., \& McDonald, L. (2006). Historical Trends in Questioning Presidents 1953-2000. Presidential Studies Quarterly, 36(4), 561-583.

Clayman, S., Elliott, M., Heritage, J., \& McDonald, L. (2007). When Does the Watchdog Bark? Conditions of Aggressive Questioning in Presidential News Conferences. American Sociological Review, 72(1), 23-41.

Clayman, S., Heritage, J. (2002). The News Interview: Journalists and Public Figures on the Air. Cambridge: Cambridge University Press.

Davis, R. (1997). Understanding Broadcast Political Talk. Political Communication, 14, 323-332.

De Fina, A. (1995). Pronominal Choice, Identity and Solidarity in Political Discourse. Text, 15(3), 379-410. 
Ekström, M. (2009). Power and Affiliation in Presidential Press Conferences: A Study on Interruptions, Jokes and Laughter. Journal of Language and Politics, 8(3), 386-415.

Ensink, T. (1997). The Footing of a Royal Address: An Analysis of Representativeness in Political Speech, Exemplified in Queen Beatrix' Address to the Knesset on March 28, 1995. In C. Schäffner (Ed.), Analysing Political Speeches (pp. 532). Bristol, PA: Multilingual Matters Ltd.

Eshbugh-Soha, M. (2003). Presidential Press Conferences over Time. American Journal of Political Science, 47(2), 348353.

Fracchiolla, B. (2011). Politeness as a Strategy of Attack in a Gendered Political Debate-The Royal-Sarkozy Debate Journal of Pragmatics, 43(10), 2480-2488.

Goffman, E. (1981). Forms of Talk. Oxford: Basil Blackwell.

Have, P.T. (1999). Doing Conversation Analysis: A Practical Guide. London: Sage.

Holly, W. (1989). Credibility and Political Language. In R. Wodak (Ed.), Language, Power and Ideology: Studies in Political Discourse (pp.115-135). Philadelphia, PA: John Benjamins Publishing Company.

Holmes, J. (1998). Women's Talk: The Question of Sociolinguistic Universals. In J. Coates (Ed.), Language and Gender: A Reader (pp. 461-483). Oxford: Blackwell.

Inigo-Mora, I. (2004). On the Use of the Personal Pronoun we in Communities. Journal of Language and Politics, 3(1), 2752.

Jaworski, A., \& Galasinski, D. (2000). Vocative Address Forms and Ideological Legitimization in Political Debates. Discourse Studies, 2(35), 35-53.

Jesperson, O. (1998). The Woman. In D. Cameron (Ed.), The Feminist Critique of Language: A Reader ( $2^{\text {nd }}$ ed., pp. 225241). London: Routledge. 
Kahn, K. (1992). Does Being Male Help? An Investigation of the Effects of Candidate Gender and Campaign Coverage on Evaluations of U.S. Senate Candidates. The Journal of Politics, 54(2), 497-517.

Kahn, K. (1996). The Political Consequences of Being a Woman: How Stereotypes Influence the Conduct and consequences of Political Campaigns. New York: Columbia University Press.

Karapetjana, I. (2011). Pronominal Choice in Political Interviews. Baltic Journal of English Language and Culture, 1, 36-45.

Khalida, N., Sholpan, Z., Bauyrzhan, B., \& Ainash, B. (2013). Language and Gender in Political Discourse (Mass Media Interviews). Procedia-Social and Behavioral Sciences, 70, 417-422.

Kitagawa, C., \& Lehrer, A. (1990). Impersonal Uses of Personal Pronouns. Journal of Pragmatics, 14, 739-759.

Kuo, S.-H. (2002). From Solidarity to Antagonism: The Use of the Second-Person Singular Pronoun in Chinese Political Discourse. Text, 22(1), 29-55.

Laberge, S., \& Sankoff, G. (1979). Anything you can do. In T. Givón (Ed.), Discourse and Syntax (pp. 419-440). New York: Academic Press.

Lakoff, R. (1975). Language and Woman's Place. Language in Society, 2(1), 45-80.

Lakoff, R. (2003). Language, Gender, and Politics: Putting "Women" and "Power" in the Same Sentence. In J. Holmes \& M. Meyerhoff (Eds.), The Handbook of Language and Gender (pp. 161-178). Oxford: Blackwell.

Maitland, K., \& Wilson, J. (1987). Pronominal Selection and Ideological Conflict. Journal of Pragmatics, 11, 495-512.

McConnell-Ginet, S. (2003). "What's in a Name?" Social Labeling and Gender Practices. In J. Holmes \& M. Meyerhoff (Eds.), 
The Handbook of Language and Gender (pp. 69-97). Oxford: Blackwell.

Mehl, M., \& Pennebaker, J. (2003). The Sounds of Social Life: A Psychometric Analysis of Students' Daily Social Environments and Natural Conversations. Journal of Personality \& Social psychology, 84(4), 857-870.

Moberg, U., \& Eriksson, G. (2013). Managing Ideological Differences in Joint Political Press Conferences: A Study of the Strategic Use of the Personal Pronoun 'We'. Journal of Language and Politics, 12(3), 315-334.

Moy, P., \& Scheufele, D.A. (2000). Media Effects on Political and Social Trust. Journalism \& Mass Communication Quarterly, 77(4), 744-759.

Mulac, A., Bradac, J., \& Gibbons, P. (2001). Empirical Support for the Gender-as-Culture Hypothesis: An Intercultural Analysis of Male/Female Language Differences. Human Communication Research, 27(1), 121-152.

Mulac, A., \& Lundell, T. (1986). Linguistic Contributors to the Gender-Linked Language Effect. Journal of Language \& Social Psychology, 5(2), 81-101.

Mulac, A., Seibold, D., \& Farris, J. (2000). Female and Male Managers' and Professionals' Criticism Giving: Journal of Language \& Social Psychology, 19(4), 389-415.

Newman, M., Groom, C., Handelman, L., \& Pennebaker, J. (2008). Gender Differences in Language Use: An Analysis of 14,000 Text Samples. Discourse Processes, 45(3), 211-236.

Perry, S. (2005). Gender Difference in French Political Communication: From Handicap to Asset? Modern and Contemporary France, 13(3), 337-352.

Proctor, K., \& Su, L. (2011). The $1^{\text {st }}$ Person Plural in Political Discourse - American Politicians in Interviews and in a Debate. Journal of Pragmatics, 43, 3251-3266. 
Rendle-Short, J. (2007). "Catherine, you're Wasting your Time": Address Terms within the Australian Political Interview. Journal of Pragmatics, 39, 1503-1525.

Smith, C. (1990). Presidential Press Conferences: A Critical Approach. New York: Praeger Publishers.

Speer, S. (2005). Gender Talk: Feminism, Discourse and Conversation Analysis. London: Routledge.

Spender, D. (1980). Man Made Language. London: Routledge \& Kegan Paul.

Tannen, D. (1990). You Just Don't Understand: Women and Men in Conversation. London: Virago.

Thomson, R., \& Murachver, T. (2001). Predicting Gender from Electronic Discourse. British Journal of Social Psychology, 40(2), 193-208.

Van Dijk T. (2003) Political Discourse and Ideology. DOXA Comunicación, 1, 207-225.

Wilson, J. (1990). Politically Speaking. Oxford: Blackwell.

\section{Websites}

Joint Press Conference with Secretary of State Condoleeza Rice and Australian Foreign Minister Stephen Smith. 25 July, 2008. Retrieved from

http://votesmart.org/public-statement/364623/joint-pressconference-with-secretary-of-state-condoleezza-rice-andaustralian-foreign-minister-stephen-smith

Joint Press Conference with NATO Secretary General Anders Fogh Rasmussen and Madeleine Albright, Chair of the Group of Experts. 17 May, 2010. Retrieved from http://www.nato.int/cps/en/natolive/opinions_63696.htm?selectedL ocale $=\mathrm{en}$ 
Remarks by President Obama and Prime Minister Gillard of Australia in Joint Press Conference. 16 November, 2011. Retrieved from

http://m.whitehouse.gov/the-press-office/2011/11/16/remarkspresident-obama-and-prime-minister-gillard-australia-joint-press

Transcript of joint press conference with US Secretary of State Hillary Clinton following their meeting in Washington D.C. (with Australian Minister for Foreign Affairs Senator the Hon Bob Carr). 24 April, 2012. Retrieved from

http://foreignminister.gov.au/transcripts/2012/bc_tr_120424.html 


\section{Appendix (1)}

\section{Joint Press Conference with Secretary of State Condoleezza Rice and Australian Foreign Minister Stephen Smith}

Statement

By: $\underline{\text { Condoleezza Rice }}$

Date: July 25, 2008

Location: Perth, Australia

MIN. SMITH: All right. Well, thanks. Everyone all right? Okay. Well, thanks very much, ladies and gentlemen. I'd just like to make some opening remarks and introduce the Secretary of State. I understand the ground rules are three per side, so I'll do my best to emcee.

Firstly, can I again, Madame Secretary, officially welcome you to Australia, to Perth, and in the course of our day, to my electorate. This is, in my view, a very significant visit. It reflects the warmth and the enduring nature of the AustraliaU.S. alliance. And it's an alliance which has served us well for over 60 years. And the alliance is enduring. Governments in Australia come and go, administrations in the United States come and go; the alliance continues to be part of the indispensable strategic security and defense arrangements between our two nations.

Of course, in addition to that, and the very many number of important regional and international issues that the Secretary and I have discussed, both in our time coming down from Singapore and the course of the day, I've endeavored to show the Secretary some of the attractions of Perth. Last night at the University of Western Australia, the Secretary was able to meet a range of Perth attributes -academic, intellectual, research, religious, sporting and commercial -- in particular, our minerals and petroleum resources industry.

This morning, we started off with coffee in Mount Lawley, at the suburb that my family have lived in since 1967 , and I was pleased to be able to introduce my mum and dad and my son and, subsequently, my daughter, to the Secretary. We then went to Mercedes College in Perth, and I think there it's true to say that the power of education and the power of equality can open up anything for any young woman or, indeed, for any young man, Australian, American, of whatever nationality. And I think, Secretary, at Mercedes, people were very much impressed by your commitment to education, what education can do in terms of 
opportunity, but also your commitment to treating people equally, irrespective of race, color, religion.

We've just come from Swanbourne Barracks with the SAS, where we paid our respects to the contribution that the SAS and Australian Defence and combat services generally make. We also met families from servicemen who have died in Afghanistan or in the Middle East in the course of the service for their country. And I was very pleased that the Secretary was able to speak to the families and pay her respects and regards to them. As you've seen, we've just laid a wreath at the State War Memorial, again, to recognize the enduring nature of the relationship, and also the joint contribution and sacrifice that Australian servicemen and women have made over a very long period of time.

So Madame Secretary, I'm very pleased to have been able to both invite and welcome you to Western Australia. Our bilateral conversations in Perth and en route from Singapore have, again, been very productive, just as our earlier ones in Washington and Kyoto and Paris have been. So we're very pleased to see you. I've certainly enjoyed the night and the day, so I hope you have. And I'd like very much to you - very much for you to make some opening remarks to the Australian and United States media, and then we'll take their questions.

SEC. RICE: Well, thank you very much, Stephen. This has been a wonderful trip. You said when we first met that I had to come to Western Australia to really see a part of Australia that was very special, and you couldn't have been more right. And Perth is a beautiful city. I've loved the opportunity to be at the University of Western Australia, a place that has a lot of links to California. I'm told that there are only -- that Herbert Hoover was here; of course, he's a Stanford alum, George Schultz, my good friend, the only other Secretary of State, also a Californian, and now, to be here.

And it was great to be with the folks there last night in the broad community from Perth. It was really wonderful to see your parents and your son and to be with Jane as well. Your parents are so proud of you and, well, they should be. But it's always great to be with people and their families, because you get a little glimpse of who they are. And I loved being there. I also loved the flat white that I enjoyed, and now I know something else that I can order and order with a kind of aplomb that says I know Australia.

I appreciated very much the opportunity to be at Mercedes College with the fine young women there, including your daughter, and of course, to pay respects to the families of the fallen and to talk with the wonderful SAS soldiers. I said 
there, and I truly do believe, that the United States and Australia share a wonderful and productive and effective alliance. We clearly have, in many, many engagements, many wars, as we've just seen, we've defended freedom together. But the reason that we've defended freedom together is we share much more. We share values and we share a fierce determination to defend our way of life and to defend our freedom. And there is no better friend for the United States than Australia.

We -- of course, in speaking to the families, I want to note to the people of Australia that the sacrifice that they've endured, of course, can never fully be repaid. There are fathers and husbands and sons who will never come back, and nothing that I can say will change that. But I hope that it is well understood that the sacrifice is appreciated, because nothing of value is ever won without sacrifice. And that is the message that I wanted to give to the families and that I give to the Australian people.

I've also appreciated the opportunity we've had to go through the complete bilateral and global agenda, both in our conversations with our colleagues at the Asian Regional Forum, but also in our bilateral discussions here. And we've covered the full range of issues in our more than two- and-a-half-hour bilateral on the plane. But I do have to reveal a little secret. We did spend a little bit of the time with Stephen trying to explain cricket to me, and I trying to explain American football to him. As long as there are no tests, I think that sooner or later, I'd like to try out my knowledge, and I hope he'll have a chance to try out his knowledge.

In short, Stephen, thank you for the invitation to this really beautiful place, this very special part of Australia. It reminds me of the Western United States, the kind of openness and optimism that is here. Being here on the grounds of this wonderful park, having visited the wonderful memorial, it's a great opportunity to celebrate what is an extraordinary relationship between the United States and Australia, and our friendship as well.

MIN. SMITH: Well, thanks very much, Madame Secretary. For the record, I should say that the bilateral lasted for three hours; one hour on regional and international matters, and hour and a quarter on cricket, and three quarters of an hour on American football.

SEC. RICE: (Laughter.)

Now, in accordance with the usual customs, the first question to the United States media. 
Q Thank you. I'm Matt Lee from AP.

SEC. RICE: Right.

Q Madame Secretary, the issue of the detainees at Guantanamo Bay has been some - has been a source of worldwide anger and frustration. You may have noticed here there were some small protests and at your next stop, in Auckland, there's a group of students who have offered a \$5,000 reward for anyone who can successfully perform a citizen's arrest on you for violations of the Geneva Convention.

I'm wondering (a), if you're aware of this and what you make of it; and, more importantly (b), how are the plans going to close down Guantanamo? Can you commit, can the Administration commit to closing it down by the time President Bush leaves office?

SEC. RICE: Well, first of all, protest is a part of democratic society, and student protests are particularly a long-honored tradition in democratic society. And I can only say that the United States has done everything that it can to end this war on terror, to live up to our international and our national laws and obligations.

Guantanamo is a detention center that, as the President has said, we would very much like to close. The problem, of course, is that there are dangerous people there who cannot be returned and put among innocent populations. We are hopeful that there will be the beginnings of the bringing to justice, the military tribunals for those people who are there. But let's not forget that a lot of innocent people have died at the hands of terrorists. And we must do everything that we can within our obligations legally and in terms of our treaty obligations to prevent that from ever happening again. And the President is dedicated to that.

We have tried to return people from Guantanamo to their home states if at all possible, but there are some people that we've not be able to do that with. And the one thing that we cannot do is to release people into a population that is innocent and would be unable to defend itself.

MIN. SMITH: Okay. First question from the Australian side.

Q Dr. Rice, this morning a student asked you if you were keen on becoming President. Have you ruled it out completely?

SEC. RICE: Yes. (Laughter.) Look, it's - I'm sure it's a great job, President. But I really -- I know what I want to do with my life. And I know the great honor that 
I've had of serving the United States as its chief diplomat. Look, the United States is an extraordinary country. It's a country that I love very, very deeply. It's a country that I've been proud to represent. It's a country that sometimes has to take difficult decisions, and we're not always popular in taking those decisions. But I hope that people know that we've always taken them in hopes of defending freedom, defending values, and making the world a better place.

And in representing my country, I've been proud to be able to say that our country's come an awfully long way. You know, I was born into segregated Birmingham, Alabama. There was actually no guarantee that my father could vote when I was born in 1954 in Alabama. And that I stand here as Secretary of State, and as I said to Stephen, in 12 years, we will not have had a white male Secretary of State. It says something very special about the United States.

And so it's a great country to represent abroad. And when I've done that - and I've got a sprint ahead of me still until I'm done, but when I am, I look forward to returning to my home. I look forward to returning to working on the many issues that concern me, but especially -- one of the reasons Stephen and I have become, I think, good friends is he has a great and abiding interest in education, as do I. And since I believe very strongly that great multiethnic societies like the United States or Australia, great multiethnic democracies, have to be certain to provide educational opportunities for their people, have to be certain that it is true that it doesn't matter where you came from; it matters where you're going, that circumstances of birth are not, in fact, a hindrance to who you will be. That's what I'd like to do, is to go back and make sure that I do my part to secure that again for America.

And so I have enormous admiration for people who do run for office, like my friend here, and we certainly put them through their paces, as an electorate should. But I know where I'm going and who I am on that score.

MIN. SMITH: Second question from the United States media.

Q Sue Pleming from Reuters. Australia has pulled its combat forces out of Iraq. Secretary Rice, would you like to see more of those forces move to Afghanistan, where there's a great need for more forces? And for both of you, do you think that Pakistan is doing a good enough job in the border areas?

SEC. RICE: First of all, let me just say how much we appreciate the contribution of Australia's forces. And we were able, because of Australia's openness and cooperation, I think, to achieve the withdrawal of Australian forces from Iraq that had been a part of the promise of the incoming Australian Government. And 
we were able to do it in a way that provided safety and consistency for the forces remaining on the ground.

And now in Afghanistan, we're fighting together in some difficult places, like Uruzgan Province, where many of the Australian forces are. And the contribution is tremendously appreciated. Look, we all have to look at what we can do. And I know that on the reconstruction and civil side, which is, after all, a part of the counterterrorism, counterinsurgency struggle as well, Australia is doing even more.

But what we need to do - it relates, Sue, to the second part of your question - is to look hard at how the Taliban is regrouping, why the Taliban is fighting in the way that they are now. They generally are taken on and defeated pretty handily when they come in actual military formations. But they certainly are - there's an uptick in the terrorism, not just against forces, but against the Afghan people. And in that regard, everybody needs to do more, but Pakistan does need to do more. That border, we understand that it's difficult, we understand that the Northwest Frontier area is difficult. But militants cannot be allowed to organize there and to plan there and to engage across the border. And so yes, more needs to be done.

MIN. SMITH: Thank you. Just to add to those remarks, firstly, in the case of Iraq, as you know, that was an election commitment, and we implemented that. That was done with the full cooperation of the United States Administration, also with the Iraqi Government and also other partners in Iraq, in particular, the British. And as a logistical exercise, that was a very, very successful exercise.

And I was in Iraq recently. In the course of being in Iraq, I announced a substantial increase in respect of Australia's contribution on the civil reconstruction side. In addition to securing peace and stability in troubled areas, we also have to give those nations the chance to grow their capacity. And so our increased assistance in Iraq goes to building state institutions, increasing capacity.

So far as Afghanistan is concerned, we have nearly a thousand troops in Afghanistan, about a thousand and 60-odd. We are the largest non-NATO contributor. We are in Uruzgan Province in the south, where the fighting is often at its most difficult and its most dangerous. And this morning, we had the pleasure of meeting people who had been in that theatre. We make a substantial contribution. We've made it clear that we don't see any increase in the combat or military or defense capability that we have in Afghanistan, but as well, in recent 
times, I've also announced, when I was in Afghanistan, a further substantial Australian contribution for nation-building and capacity- building.

We are very grateful for the role that our forces play in Afghanistan. And at Swanbourne Barracks, I said to some of the regiment there that they do really need to understand that the work they do in difficult and dangerous circumstances is very genuinely appreciated by our friends and allies. I also made the point that - and in the vernacular, that the work they do in conjunction with our friends and allies, whether it's combat or a peacekeeping role, helps give Foreign Ministers of Australia street cred when they walk in the door. That is unambiguously the case. And it's a very important role that they play for international peace and security, but an important role they play on behalf of their nation.

When it comes to Pakistan, I have made the point, as I did to the Pakistan representatives in Singapore in the course of the ASEAN Regional Forum, that we are very concerned about the Afghanistan- Pakistan border area. We don't believe that that can be regarded simply as a bilateral matter between Pakistan and Afghanistan. It is an issue which has regional and international community consequences. There is no doubt that the current international hotbed of terrorism is in that area, is in the Pakistan border area in Afghanistan.

One thing we know about modern terrorism: it is mobile and moves very quickly, either north and west to Europe, or south and east to Asia. And Australia has already been on the receiving end and adverse consequences of terrorist activity in Southeast Asia. So we have raised the border issue with the Pakistan Government, as we have with our ally, the United States, and other friends in Afghanistan, in particular, the British.

But this is an area where both the regional community and the international community needs to do more. We do need to engage Pakistan more in a dialogue and we do need, in my view, to be rendering assistance to Pakistan at a time which is very, very difficult for them.

Second question, Australian media.

Q Dr. Rice, Western Australia is a state with significant uranium reserves. Has your agreements or talks with India and Australia's role and what part we could play come up in your talks? Do you think there's a role for us there?

SEC. RICE: Well, we have talked about the U.S.-India Civil Nuclear Deal. I'll ask Stephen to speak to the Australian position, but the -- we've made very clear 
that we believe that this is an agreement that serves the interests of the U.S.Indian strategic relationship. It serves the interests of India in terms of its needs for energy that is not hydrocarbons-based. They want a civil nuclear program and this is a way for them to have one.

And frankly, it serves the interests of the nonproliferation regime. India is not a party to the NPT, but the regime, the broader regime, is one in which even nonNPT states need to take certain obligations in terms of proliferation, and India has a good record in terms of proliferation. And the fact that Mohamed ElBaradei, the Director General of the IAEA, has been supportive of this deal, I think, supports the notion that this is good for the international nonproliferation regime.

I know that there will be consultations coming up soon in the IAEA Board of Governors, and then in the Nuclear Suppliers Group. Australia, of course, will participate in those. And I don't expect that Australia has yet to make a decision. That's not what's being asked, but I know that I've had -- I found a very open hearing and listener as we've put forward the case for this deal and -- as the Indians have, as well.

MIN. SMITH: Well, there are two separate issues. First is the export of Australian uranium. The government has a longstanding party policy position which is we don't export uranium to a country that is not a party to the Nuclear Nonproliferation Treaty. And I've made that clear to Indian officials and the Indian Government pretty much from day one of the new Australian Government's term in office.

The India-U.S. nuclear civil arrangement is a separate matter, and a matter, indeed, that my memory is, Secretary, that when we first met in Washington, we discussed it there, as we have regularly, and as I have with Indian officials and Minister Mukherjee, recently, and as the Prime Minster did, Prime Minister Rudd, with Prime Minister Singh in the margins of the G-8 meeting recently.

Our position on the U.S.-India civil nuclear arrangement is that if and when the arrangement emerged from, effectively, the Indian parliament to the Nuclear Suppliers Group and the International Atomic Energy Agency, then we would put our mind to the detail of the agreement. The vote of confidence in the Indian Prime Minister and the Indian Government in the course of this week now makes it almost certain that the arrangement will proceed to the Nuclear Suppliers Group and the International Atomic Energy Agency's Board of Governors. 
The fact that our policy position prevents us from exporting uranium to India does not prevent us from joining a consensus to support the Civil-Nuclear Deal. And I've indicated both to the Indian Minister of State, who was in Singapore, and to the Secretary of State, that we are now looking in detail at the arrangement and agreement, looking at the views of other players in the Nuclear Suppliers Group and the Atomic Energy Agency itself. And we're doing that with a positive and constructive frame of mind. We don't proceed on the basis that our policy position on the export of uranium prohibits or prevents us from supporting that arrangement, and so we're looking at it in a positive and constructive manner. And we're also, as I've made clear consistently to the United States and India, when we do that assessment, looking very carefully at the strategic importance that both the United States and India place on this arrangement.

I think it's third strike. You're out over here.

Q Yes. I'm Lachlan Carmichael from AFP news agency. Madame Secretary, you've been telling us -- Madame Secretary, you've been telling us about progress made privately between the Israelis and Palestinians towards a draft peace agreement. Next week, there will be the trilateral in Washington. Will you be able, finally, to give some public details of the progress they've been making, and will you be applying pressure to (inaudible) both sides into that deal you really want before you leave office - or before President Bush leaves office?

SEC. RICE: Well, the first answer is no. We won't be providing details of what goes on in the trilateral. They are -- the Israelis and the Palestinians have their first serious peace process in seven years, and they are discussing very sensitive and difficult issues. I would remind that the most effective negotiations they probably ever had were Oslo, and no one even knew they were negotiating. And they -- so I think they're really rather wise to negotiate seriously, to work with each other, to see if they can overcome differences without having a daily accounting of how well they're doing or how badly or who's up or who's down. And that's what they want to avoid. And I'm going to stick scrupulously to the same view.

I think the United States can help them to see where there are points of convergence, and that's what I generally do in the trilaterals. I think I can also because I stay in very close contact with all of my colleagues in the international community, including Australia, I think I can represent to them some of the things that the international community might be willing to do to help them in getting to a deal or in making the deal work. 
Now, there is still time for them to, in accordance with Annapolis, reach agreement by the end of the year. And we'll keep working toward that goal. But the most important thing right now is to take note of how very seriously they are negotiating, to note that there was not, even last year, a peace process at this time, and to recognize that since this President came into office, the notion of two states living side by side in peace and security has just become kind of common wisdom; we all say it. Well, in fact, in 2001, that was not the position either of the Likud government of Ariel Sharon, or of much of the international community.

And so the President has, in stating clearly American policy for a two-state solution, in helping to get through the extraordinary difficult years of 2001, 2002, 2003, the second Intifada, in helping to get through the withdrawal from Gaza, the Lebanon War, and then launching Annapolis, I think has laid a firm foundation on which these two parties can finally end their conflict. The work now is to keep pressing ahead, but pressing ahead in a way that preserves the workability of this process. And that really means preserving the confidentiality of their discussions.

MIN. SMITH: Okay, last one. We've had the two opening (inaudible) from the Australian side. Now, it's first change.

Q Dr. Rice, if we could just lighten up as we wrap up here. President Bush is coming to the end of his term. Over the years, satirists have had a bit of fun with him. In Australia, he may be seen as a larrikin. What's he like as a boss?

SEC. RICE: President Bush, what's he like as a boss?

Q Yeah.

SEC. RICE: Well, he is somebody who really proceeds from a kind of deep sense of principle, and he sometimes finds things outrageous. He finds -- I mean, he's outraged by certain things. And I'll tell you something that he finds very difficult to deal with. He finds it difficult when he sees people who live in tyranny. I know that that's considered somewhat old fashioned, to believe that no man, woman or child should have to live in tyranny, but as somebody who himself is free, he's offended by the continuance of dictatorships in this world.

Now, I think that has united us and united this Administration. I know that there's sometimes a misreading of that to suggest that we're somehow naive, that on our watch, all dictatorships were going to go away, we were going to end tyranny for all time. That's not the point. Because everyone understands that the 
ending of tyranny is a long, long, long term process that takes generations and generations. But if somebody doesn't speak up for the principle that it's simply wrong for men and women to live in the absence of freedom, then it's never going to happen.

And you know, I'm a firm believer that it's all right to be a little bit on the side of too optimistic and too idealistic, rather than too cynical and too pessimistic about human beings and what they can achieve. Because if you look back over history, whether it was the founding of the United States of America itself, which probably never should have come into being, given the great struggles against the British Empire or our own Civil War, which almost did end the American experiment; to the collapse of a country with 30,000 nuclear weapons and 5 million men under arms peacefully without a shot, in one night the hammer and sickle came down, the tricolor went up; did we think any of that possible? Well, those things that seemed impossible now seem, in retrospect, inevitable.

So I think the President is someone who, if he has to err, he'll err on the side of idealism and optimism. And you know, when you have to get up and go to work every day post-9/11, where for us, quite frankly, every day is September 12th, it's an awfully good thing to work for somebody and for the President of the United States who really is, at heart, an idealist and an optimist.

Thank you.

MIN. SMITH: Thanks very much.

SEC. RICE: Thank you.

MIN. SMITH: Thanks, ladies and gentlemen.

END. 


\section{Appendix (2)}

17 May. 2010

Joint press conference with NATO Secretary General Anders Fogh Rasmussen and Madeleine Albright, Chair of the Group of Experts

NATO Secretary General Anders Gogh Rasmussen : I have been looking very much forward to this day, the presentation of the Report on the New Strategic Concept from the Group of Experts under leadership of Secretary Albright. First, let me thank Secretary Albright, Mr. van der Veer and all the members of the Group for the hard work they've put into preparing this excellent Report. I selected each member for his or her experience, expertise and energy. I had high expectations, and they have been fully met.

When I launched this process, I emphasised that it should be the most transparent and inclusive in NATO's history. The Group shared that view and took it to heart. They consulted very broadly: from NATO experts, to parliamentarians, to think tanks and academics, to the general public, in NATO and Partner countries. This Report has a small number of authors, but thousands of contributors. And I believe it is the better for it.

This Report is not the Strategic Concept itself, but it is a very important first step in preparing the new Concept. The Report is now on our website, and I'm sure it will stimulate quite some discussion. I will follow the debate closely, and take both the Report and the discussion into account when I prepare the first draft of the Strategic Concept itself, as you know it which will be approved by Heads of State and Government in Lisbon this November.

This Report is a very solid basis for the discussions to come. The Group has taken a hard look at global security trends, and given a frank and honest assessment of those areas where we need to transform, in order to be fully up to meeting the security challenge of the 21 st Century.

I will leave it to Secretary Albright to present the findings of the Report to you. But let me touch briefly for you some of what I consider to be some of the highlights.

First: the report confirms that NATO's foundations are as important as ever, and should only be reinforced: the transatlantic link; the commitment to collective defence; the openness to new members. NATO's core purpose was, is, and will remain to provide for the security of its members.

But the Report is equally clear that, these days, providing for the security of our members means doing many things differently. Among many important points: 
It means taking on new challenges, such as cyber-attacks and missile attacks.

It means broadening our political consultations within NATO, and making fuller use of Article 4 of the Washington Treaty.

It means engaging much more intensely and more broadly with global partners. As the Report says, Partnerships will be a central part of our daily work. I fully agree.

In the execution of operations it means a comprehensive approach that combines military and civilian elements. These are the lessons learnt from Afghanistan.

It means working for a real partnership with Russia - based on shared interests and reciprocity.

And it means reforming this organisation. The Report is very clear that NATO reform is not just a nice slogan; it is essential. And I fully share this view.

There is a lot more in there. So let me now turn to Secretary Albright to present the Group's work in more detail, after which we will be happy to take your questions. And I close by thanking Secretary Albright, Jeroen van der Veer and all the members of the Group of Experts very much for your excellent work, on behalf of all the Allies.

And before giving the floor to Secretary Albright let me extend a special word of appreciation to you, your energy, your vast diplomatic experience and your leadership have guided the Group skillfully to this successful conclusion. And I cannot think of anybody else who could have performed this challenging task so well.

MADELEINE ALBRIGHT (Chair of the Group of Experts) : Thank you very much, Mister Secretary General. And it has indeed been my honor to have chaired this remarkable group of experts to report with you and the terrific staff at NATO. I think this has been one of the most interesting tasks that I have been given.

I grew up with NATO. It is to me a very important alliance. And I'm delighted to have had the opportunity to participate in providing some of the building blocks for your strategic concept that will indeed make clear that this is a 21 st century alliance.

I think that we took in some ways the concept that, in fact, the alliance in the 21 st century has to be agile and flexible in a time of unpredictability. And that it 
was very important to do two things is to truly reassure the members of NATO that article 5 remains a core aspect of the Alliance and that at the same time that we are prepared in order to promote the security of the Alliance to be willing to take on challenges abroad.

So the title... excuse me... of Short Security and Dynamic Engagement does in fact reiterate the importance of article 5 and the dynamic engagement emphasizes that we need to deepen our partnerships and work cooperatively to prevent the challenges that emanate from beyond the North Atlantic region from actually reaching our shores.

I think that it's very clear that an Alliance in the 21 st century needed to have some adjustments because the threats are so totally different. I call this a little bit a renewal of our vows that NATO cannot let the 21 st dangers divide leaders and weaken our collective resolve. That it is important that at this stage we understand who we are and how we're going to operate.

I think that what is new in this report is that the report is the first opportunity to reflect on what NATO has done since the last strategic concept in 1999. The Alliance is obviously larger and has to respond from threats around the world. And therefore I think this new concept of partnership is something that needs to be focussed on much more.

We call for enhanced partnerships for many nations and other international organizations and non-governmental entities. We also call for enhanced political consultations and crisis management mechanisms. And we are looking at ways how to deal with new threats from non-State actors.

We have also made some proposals as the Secretary General has mentioned on how to make progress with Russia. And we have stressed the need to improve NATO's efficiency and effectiveness. I think that we have understood throughout this process something that the Secretary General emphasized which is the importance of transparency and public support.

We are an Alliance of democracies which is the basis of the Alliance itself, which obviously means that our publics need to understand what this is all about in the 21 st century. So I think that we have in fact pointed out that we need to reaffirm our... a cooperative view of Atlantic security order and that we need to reach out to the partners in order to deal with the unpredictability in the $21 \mathrm{st}$ century. And I think now we're happy to answer questions. 
But Mister Secretary General, let me end by saying that I thank you tremendously for your support and friendship in this. You now have the difficult job of taking these various building blocks and consulting further and providing the Alliance with the leadership that it needs in this very challenging century. And thank you so much for the confidence that you put in all of us for asking us to help you. Thank you.

17 May. 2010

Questions and answers

at the joint press conference with NATO Secretary General Anders Fogh Rasmussen and Madeleine Albright, Chair of the Group of Experts

\section{JAMES APPATHURAI (NATO Spokesman): Ben.}

Q: Ben Nimmo for the German Press Agency here in the middle. Two questions if I might for both of you. First of all, on missile defense, we understood that the November Lisbon Summit would be deciding whether or not missile defense should become a NATO mission. I read in the report that it has become for NATO an essential military mission. So can you just clarify where exactly are we on the missile defense debate? Is it now decided that that's a NATO mission or do we wait for November till that one? And on the question of Russia, Russia has identified NATO enlargement around its borders as a threat to its security. So how do you reconcile improving relations with Russia with insisting on the open door policy? Thank you very much.

MADELEINE ALBRIGHT: You want... the first one?

ANDERS FOGH RASMUSSEN: Yes. On missile defense, we have not yet decided whether missile defense can or should be considered an Alliance mission. This is for the summit in November to decide. This is an independent report from an independent group. This group considers, apparently, missile defense an important Alliance mission. I could add to this that, personally, I fully agree with the group of experts. But of course, at the end of the day, it is for Allies to decide. But in my opinion, there's no doubt. We are faced with a real threat. And we need a real protection against a real threat. And to that end, we need an effective missile defense system which covers all populations in all Allied nations.

MADELEINE ALBRIGHT: Let me say that we, as an independent group, did in fact recommend that it be a mission as the Secretary General has stated. And we are an Alliance that is defensive and needs a deterrent. And that is the basis on 
how that was stated. But obviously, as Secretary General said, that will be a decision made by the heads of government and State.

On the issue of Russia, let me just say that, when we went to Russia, we had this particular discussion and tried to make clear that NATO is not directed at any particular enemy, that we do not see the gradual enlargement of NATO on the basis of article 10 as something that should be viewed as a threat to Russia. And we all believe that and we will continue to state it. And the Russians, in their own turn, have to decide how they react.

But the bottom line is that there are many aspects of this report that indicate that we see any number of ways that the Alliance can cooperate with Russia on dealing with common threats. And so it is an open door open hand in terms of dealing with Russia.

UNIDENTIFIED: Dmitry Shkurko, National News Agency of Ukraine. Secretary Albright, just follow-up of the question of my colleague. In the current geopolitical circumstances, do you consider any geographical limits for NATO open door policies? And to Secretary General please, don't you think that all the current developments around Ukraine means some kind of lost opportunities for entire process of EuroAtlantic integration? Thanks.

MADELEINE ALBRIGHT: I think that we restated that NATO should retain an open door policy based on the previous criteria that have been used. And we also made very clear that NATO is an entirely voluntary organization. So the guidelines and criteria that have been used for previous membership is the same; will continue the same.

ANDERS FOGH RASMUSSEN: As far as Ukraine is concerned, NATO policies still stand. We decided in 2008 that Ukraine, and by the way also Georgia, will become members of NATO if they so wish and if they fulfill the necessary criteria. Right from the outset, we have stated that, of course, it is for each individual country, also for Ukraine, to decide its own path. And I have taken of the fact that the government of Ukraine has stressed that it will continue to cooperate with NATO within the current framework of NATO-Ukraine Commission.

Q: (Inaudible)... Radio and Television. Secretary Albright, in the next few years, a lot of public budgets, at least in Europe, will see massive cuts and austerity. Is that reflected in your report? Did you consider that? And Secretary General, how concerned are you that this climate, this economical climate, will impact negatively on your organization? Thank you. 
MADELEINE ALBRIGHT: We did reflect that there clearly were economic issues. But we also talked about the necessity of fulfilling the responsibilities that NATO membership brings in terms of support for this Alliance and the fact that it is an alliance in which there are shared responsibility. And that the public... This is one reason that I think we believe that the publics need to understand the value of NATO and what it is they get for the budgets that they put in. And the necessity of streamlining some of the decision-making in terms of buying, having a common funding, trying to figure out ways of procurement that make sense in the 21 st century.

ANDERS FOGH RASMUSSEN: Obviously, the current economic climate is a challenge. Many countries have been forced to make deep cuts in government budgets, including defence budgets. And from a long-term perspective, this is, of course, a matter of concern. Also, if we'll see a deepening of the gap between North America and Europe as far as defence investments are concerned.

Having said that, I also think governments could take advantage of the crisis, if I may use that term, and use the budgetary constraints as a leverage for necessary reforms and transformation to make sure that we really get value for money and make efficient use of our resources.

JAMES APPATHURAI: Brooks.

Q: Yes, Brooks Tigner, Jane's Defence. I want to come back to the reform issue which I pressed the Secretary General on before and ask this to you Madam Albright. In your call for increasing NATO's efficiency, does this mean reducing the size of political and military committees and structures across NATO? That's something NATO has not managed to do in any significant way since the fall of the Berlin Wall. And related question, what does this mean for dealing with nonState actor threats in ways different than NATO has done in the past? Thank you.

MADELEINE ALBRIGHT: Well, we certainly understood the problems of bureaucratic expansion and various committee growth and specifically gave authority or asked that authority be given to the Secretary General to work further on his reform projects to streamline.

We felt that we were not in a position to specifically dictate which committees or what, but really felt that it was necessary, in this day and age, to streamline the decision, the number of committees and the way that they work together. And it has something to do with the previous question in terms of budgets. I think we believe that we need to... that NATO needs to spend smarter. And I think that that will be very important. 
The other part on the non-State actors, we did note specifically some of the problems that are raised as a result of non-State actors, be it terrorism, cybersecurity, disruption of various maritime traffic lanes, etc. So we point all those up and say that is important for NATO to begin to address itself more to those kinds of non-State threats.

Q: Claus... Claus Hecking from Financial Times, Deutschland. Could you just go a little bit into detail on the role of Mister van der Veer? Was he just responsible for energy security or was it much broader - his role? Thanks.

MADELEINE ALBRIGHT: No, Mister van der Veer was the vice-chair. And he was somebody that spent a great deal of time on all the subjects. And if I were to say one thing that he really focussed on was public support. I think that is something that he has spoken about from the very beginning and also in terms of rationalizing a lot of the decision-making.

He has been a full partner in this whole project. And I must say that all the experts contributed an incredible amount of time and knowledge and hard work. We divided it up into a variety of working groups and - I think, Mr. Secretary General - probably worked harder than you thought we would. But we really spent a lot of time and everybody - I think - was very dedicated to this challenge.

ANDERS FOGH RASMUSSEN: May I just add to this that I selected Mr. van der Veer because I also wanted a private sector perspective on this work. And we have really profited from that in our deliberations.

JAMES APPATHURAI: Jim.

JIM NEUGER: Jim Neuger from Bloomberg. Just wanted if you could say more about how you see NATO's potential partnership with China developing, especially if you regard Central Asia as one of the principal hot spots for the next 10 years. And also on the matter of peacekeeping, what should NATO's future role in peacekeeping be? Especially if there is a peace in the Middle East, would you recommend that NATO forces serve in a peacekeeping operation there?

MADELEINE ALBRIGHT: Well, let me say that we were quite open minded, I think, in terms of the possibilities of partnership in the broader spaced way, that not only the kind of... ones that one might think right of. We made a very special point about partnership with the European Union. And then we obviously talked about Russia and just generally partnership. We did mention the importance of 
looking into ways of partnering with China on a variety of issues. But obviously, I think, that is something that needs to be explored.

The issue generally of peacekeeping, and let me just say this - this is something with which I had some previous experience - I think that it is important to try to find the right organization and right tool for peacekeeping. And one of the aspects that we talked about was how various organizations partner together on peacekeeping operations.

We did leave open the possibility that - if the parties were interested and if there were a peace to keep in the Middle East - that this was a potential possibility. But I've used many subjunctive phrases here, because it was just something that was discussed in one of our seminars.

Q: My name is Nadia Demanska, I am from Ukrainian television and my question for Mr. Secretary General. I know that you promised to make the new concept as the most transparent in NATO history and even asked bloggers to send some interesting ideas. Are there any results and exotic propositions from the Internet?

\section{ANDERS FOGH RASMUSSEN: (inaudible)}

Q: You posted, sorry, word for bloggers, for Internet users. Are there any ideas from the people from Internet concerning the new concept of NATO?

ANDERS FOGH RASMUSSEN: I think that several of the ideas presented by bloggers and other participants from the broader public have been represented in the groups' report, maybe not exactly in the form in which they were presented on the net. But eventually, they establish a platform for proposals which have been reflected in the group's report. We have really enjoyed that so many people have contributed to our work. And I hope that they will continue discussion as we approach the summit in November.

JAMES APPATHURAI: We have time for one more question.

Q: (Inaudible) from the EU Observer. Coming back to the spending issue, taking into account the fact that most of the NATO members are also EU members and the EU is now developing a stronger defence policy and it has its own defence agency that looks at streamlining defence spending, to what extent do you take that into account in the new concept? And how do you plan to be more efficient in how European member States plan their defence budgets? Thank you. 
MADELEINE ALBRIGHT: Well, let me just say we take note of the fact that the taxpayers are the same for most of the countries. And that it is very important to be efficient and try to figure out ways where, in fact, the two organizations can cooperate so that there is not a duplication in terms of effort, and a way that there can in fact be a maximization of the various potential of these two great organizations.

JAMES APPATHURAI: I'm afraid that's all we have time for. Thank you.

MADELEINE ALBRIGHT: Thank you very much.

ANDERS FOGH RASMUSSEN: Thank you. 


\title{
Appendix (3)
}

The White House

Office of the Press Secretary

For Immediate Release

November 16, 2011

\section{Remarks by President Obama and Prime Minister Gillard of Australia in Joint Press Conference}

\author{
Parliament House
}

Canberra, Australia

\section{6:10 P.M. AEST}

PRIME MINISTER GILLARD: Good evening, one and all. I take this opportunity to very warmly welcome President Obama to Australia for his first visit as President. President Obama is no stranger to our shores, having visited Australia before. But it is a special delight to have him here for his first visit as President. And it comes at an important time in our nation's history and in the history of our region.

We will be looking back during this visit -- we'll be looking back at 60 years of the ANZUS alliance. We'll be looking back 10 years to the dreadful day of 9/11, a day we all remember with great sorrow. And we will be reflecting on those events. But we will be looking forward.

We live in the growing region of the world where its global -- contribution to global growth is a profound one. We live in a region which is changing, changing in important ways. And as a result of those changes, President Obama and I have been discussing the best way of our militaries cooperating for the future.

So I'm very pleased to be able to announce with President Obama that we've agreed joint initiatives to enhance our alliance -- 60 years old and being kept robust for tomorrow. It is a new agreement to expand the existing collaboration between the Australian Defence Force and the U.S. Marine Corps and the U.S. Air Force. What this means in very practical detail is from mid-2012, Australia 
will welcome deployments of a company-size rotation of 200 to 250 Marines in the Northern Territory for around six months at a time.

Over a number of years, we intend to build on this relationship in a staged way to a full force of around 2,500 personnel -- that is a four Marine Air Ground Task Force.

A second component of these initiatives which we have agreed is greater access by U.S. military aircraft to the Royal Australian Air Force facilities in our country's north. This will involve more frequent movements of U.S. military aircraft into and out of northern Australia. Now, taken together, these two initiatives make our alliance stronger, they strengthen our cooperation in our region.

We are a region that is growing economically. But stability is important for economic growth, too. And our alliance has been a bedrock of stability in our region. So building on our alliance through this new initiative is about stability. It will be good for our Australian Defence Force to increase their capabilities by joint training, combined training, with the U.S. Marines and personnel. It will mean that we are postured to better respond together, along with other partners in the Asia Pacific, to any regional contingency, including the provision of humanitarian assistance and dealing with natural disasters.

In addition to discussing this global force posture review by the United States and these new initiatives in our alliance, the President of the United States and I have had an opportunity to reflect on a number of other issues -- to reflect on circumstances in the global economy; to reflect on a clean energy future for our nations and for our planet; to reflect on the forthcoming East Asia Summit. President Obama will proceed from Australia to that summit in Indonesia, where he spent time growing up.

We've had a comprehensive discussion. I very much welcome President Obama to Australia. I think he's already seen that the welcome he's getting from Australians, including Australian schoolchildren, is a very warm one. And I 
know that that is going to be sustained during tonight's events and the events of tomorrow.

President Obama, over to you.

PRESIDENT OBAMA: Good day, everybody. And thank you, Madam Prime Minister, for your generous welcome, your friendship and your partnership. I am thrilled to be Down Under.

As you may know, this is not my first visit to Australia. In fact, I first visited Australia as a boy. And I've never forgotten the warmth and kindness that the Australian people extended to me when I was six and eight. And I can see that the Australian people have lost none of that warmth.

I very much wanted to take this trip last year, and although events back home prevented me from doing so, I was determined to come for a simple reason: The United States of America has no stronger ally than Australia. For nearly a century, we've stood together in defense of the rights and freedoms that we cherish. And I'm very happy to be here as we celebrate the 60th anniversary of our alliance, and as we work together to strengthen it for the future.

We are two Pacific nations, and with my visit to the region I am making it clear that the United States is stepping up its commitment to the entire Asia Pacific. In this work, we're deeply grateful for our alliance with Australia and the leadership role that it plays. As it has been for six decades, our alliance is going to be indispensable to our shared future, the security we need and the prosperity that we seek not only in this region but around the world.

I'm also very grateful for my partnership with Prime Minister Gillard. We've worked quite a bit together lately --

PRIME MINISTER GILLARD: You bet.

PRESIDENT OBAMA: -- spanning time zones -- the G20 in Cannes, APEC, and TPP in Hawaii, now here in Australia, and next onto Bali for the East Asia 
Summit. And this speaks to how closely our countries work together on a wide range of issues. And in my friend, Julia, I see the quality that we Americans admire most in our Australian friends: somebody who's down to earth, easy to talk to, and who says it like it is -- straight up. And that's why we achieved so much today.

We agreed to push ahead with our efforts to create jobs for our people by bringing our economies and those of the region even closer together. Building on our progress at APEC, we're going to keep striving for a seamless regional economy. And as the two largest economies in the Trans-Pacific Partnership, Australia and the United States are helping to lead the way to a new model for trade across the region. And along with our G20 partners, we agreed that we have to stay focused on the growth that creates jobs, and that every nation needs to play by the same economic rules of the road.

As two global partners, we discussed the whole range of challenges where we stand shoulder to shoulder, including Afghanistan. Obviously, this has not been an easy mission for either of our countries, and our hearts go out to the families that were affected on October 29th. But we both understand what's at stake -what happens when al Qaeda has safe havens. We've seen the awful loss of life - from 9/11 to Bali.

So I thanked the Prime Minister for Australia's strong commitment to this mission. I salute the extraordinary sacrifices of our forces who serve together, including your Australian troops who've shown that no job is too tough for your "Diggers." Today, the Prime Minister and I reaffirmed the way forward. The transition has begun. Afghans are stepping into the lead. As they do, our troops -- American and Australian -- will draw down responsibly together so that we preserve the progress that we've made, and by 2014, Afghans will take full responsibility for security in their country.

But our focus today, as the Prime Minister said, was on preparing our alliance for the future. And so I am very pleased that we are able to make these announcements here together on Australian soil. Because of these initiatives that 
are the result of our countries working very closely together as partners, we're going to be in a position to more effectively strengthen the security of both of our nations and this region.

As Julia described, we are increasing our cooperation -- and I'd add, America's commitment to this region. Our U.S. Marines will begin rotating through Darwin for joint training and exercises. Our Air Force will rotate additional aircraft through more airfields in Northern Australia. And these rotations, which are going to be taking place on Australian bases, will bring our militaries even closer and make them even more effective. We'll enhance our ability to train, exercise, and operate with allies and partners across the region, and that, in turn, will allow us to work with these nations to respond even faster to a wide range of challenges, including humanitarian crises and disaster relief, as well as promoting security cooperation across the region.

And this commitment builds upon the best traditions of our alliance. For decades, Australians have welcomed our service members as they've come here to work, train, and exercise together. And I'm looking forward to joining the Prime Minister in Darwin tomorrow to thank our troops -- Australians and Americans -- for the incredible work that they are doing.

Finally, as I'll discuss more in my speech to Parliament tomorrow, this deepening of our alliance sends a clear message of our commitment to this region, a commitment that is enduring and unwavering. It's a commitment that I'll reaffirm in Bali as the United States joins the East Asia Summit. And I want to thank our Australian friends who supported our membership so strongly and have worked to make sure that the EAS addresses regional challenges that affect all of us like proliferation and maritime security.

So, again, I'm very pleased that we're able to make these important announcements during my visit. Madam Prime Minister, I thank you for being such a strong partner and a champion of our alliance. 
And once again, I want to thank the Australian people for the kindness they showed me about 40 years ago, and the kindness that they're showing me during my visit today. It's that friendship and that solidarity that makes and keeps our alliance one of the strongest in the world.

PRIME MINISTER GILLARD: Thank you.

We'll turn to taking some questions. I think we'll probably take one from the Australian media first. Phil Hudson.

Q Philip Hudson from the Melbourne Herald Sun. Mr. President, welcome back to Australia.

PRESIDENT OBAMA: Thank you very much.

Q You and Prime Minister Gillard have outlined what is for us a significant new U.S. troop buildup. How much of this is because you're (inaudible) of China? And as of today's deal, U.S. Marines will be for the first time conducting exercises by themselves on Australian soil. Why is that, and what will they be doing?

And, Mr. President, you also mentioned in your remarks that Afghanistan is not an easy mission. In the past few months there have been three cases for Australia where our troops have been shot at by the Afghan soldiers who have been training and, sadly, four of our soldiers have died and many others have been injured. Australian public opinion is strongly against our involvement continuing. You've outlined the -- just then, the drawdown. What can you say to the Australian people who don't want to wait, who want to leave immediately?

PRESIDENT OBAMA: Well, first, with respect to these new initiatives, this rotational deployment is significant because what it allows us to do is to not only build capacity and cooperation between our two countries, but it also allows us to meet the demands of a lot of partners in the region that want to feel that they're getting the training, they're getting the exercises, and that we have the presence that's necessary to maintain the security architecture in the region. 
And so, as Julia mentioned, this is a region that's becoming increasingly important. The economy in this area is going to be the engine for world economic growth for some time to come. The lines of commerce and trade are constantly expanding. And it's appropriate then for us to make sure that not only our alliance but the security architecture of the region is updated for the $21 \mathrm{st}$ century, and this initiative is going to allow us to do that.

It also allows us to respond to a whole host of challenges, like humanitarian or disaster relief, that, frankly, given how large the Asia Pacific region is, it can sometimes be difficult to do, and this will allow us to be able to respond in a more timely fashion and also equip a lot of countries, smaller countries who may not have the same capacity, it allows us to equip them so that they can respond more quickly as well.

And I guess the last part of your question, with respect to China, I've said repeatedly and I will say again today that we welcome a rising, peaceful China. What they've been able to achieve in terms of lifting hundreds of millions of people out of poverty over the last two decades has been nothing short of remarkable. And that is good not just for China, but it's potentially good for the region. And I know Australia's economy, obviously, has benefitted by the increased demand that you're seeing in China.

The main message that I've said not only publicly but also privately to the Chinese is that with their rise comes increased responsibilities. It's important for them to play by the rules of the road and, in fact, help underwrite the rules that have allowed so much remarkable economic progress to be made over the last several decades. And that's going to be true on a whole host of issues.

So where China is playing by those rules, recognizing its new role, I think this is a win-win situation. There are going to be times where they're not, and we will send a clear message to them that we think that they need to be on track in terms of accepting the rules and responsibilities that come with being a world power. 
With respect to Afghanistan, the impact of any loss of life among our troops is heartbreaking. And obviously, as President of the United States, there's no greater responsibility and nothing more difficult than putting our troops in harm's way. I think Prime Minister Gillard feels the same way that I do, which is we would not be sending our young men and women into harm's way unless we thought it was absolutely necessary for the security of our country.

What we have established is a transition process that allows Afghans to build up their capacity and take on a greater security role over the next two years. But it's important that we do it right. As some of you are aware, I just announced that all remaining troops in Iraq will be removed. It would have been tempting, given that I have been opposed to the Iraq war from the start, when I came into office, to say, we're going to get you all out right away. But what I recognized was that if we weren't thoughtful about how we proceed, then the enormous sacrifices that had been made by our men and women in the previous years might be for naught.

And what I'd say to the Australian people at this point is, given the enormous investment that's been made and the signs that we can, in fact, leave behind a country that's not perfect, but one that is more stable, more secure, and does not provide safe haven for terrorists, it's appropriate for us to finish the job and do it right.

PRIME MINISTER GILLARD: If I could just add to that and say, every time I have met President Obama and we've talked about our alliance, we've talked about our work in Afghanistan, and in our meetings, both formal and informal, the President has shown the greatest possible concern for our troops in the field. The meetings we've had over the last few weeks at various international events have coincided with some of the most bitter and difficult news that we've had from Afghanistan, and every step of the way the President has gone out of his way to convey to me his condolences for the Australian people and particularly for the families that have suffered such a grievous loss.

PRESIDENT OBAMA: Laura MacInnis, Reuters. 
Q Thank you, Mr. President. Chancellor Merkel said this week that Europe is in its toughest hour since World War II. Markets are now showing some anxiety about the possibility of instability spreading to France as well. Are you worried that the steps European leaders are taking are too incremental so far? Do you think something bolder or a more difficult set of decisions need to be taken to fully (inaudible) that crisis?

I have a question for Prime Minister Gillard as well. Are you concerned that the fiscal pressures the United States is under at the moment may compromise its ability to sustain its plans for the region, including the initiatives announced today? Do you have to take those with something of a grain of salt until the super committee process is concluded?

PRESIDENT OBAMA: With respect to Europe, I'm deeply concerned, have been deeply concerned, I suspect we'll be deeply concerned tomorrow and next week and the week after that. Until we put in place a concrete plan and structure that sends a clear signal to the markets that Europe is standing behind the euro and will do what it takes, we're going to continue to see the kinds of turmoil that we saw in the markets today -- or was it yesterday? I'm trying to figure out what -- (laughter) -- what time zone I'm in here.

PRIME MINISTER GILLARD: It's all of the time.

PRESIDENT OBAMA: All of the -- right. (Laughter.) We have consulted very closely with our European friends. I think that there is a genuine desire, on the part of leaders like President Sarkozy and Chancellor Merkel, to solve this crisis. But they've got a complicated political structure.

The problem right now is a problem of political will; it's not a technical problem. We saw some progress with Italy and Greece both putting forward essentially unity governments that can implement some significant reforms that need to take place in those countries. But at this point, the larger European community has to stand behind the European project. And for those American readers or listeners, and those Australian readers or listeners, I think we all 
understand at this point we've got an integrated world economy and what happens in Europe will have an impact on us.

So we are going to continue to advise European leaders on what options we think would meet the threshold where markets would settle down. It is going to require some tough decisions on their part. They have made some progress on some fronts -- like their efforts to recapitalize the banks. But ultimately what they're going to need is a firewall that sends a clear signal: "We stand behind the European project, and we stand behind the euro." And those members of the eurozone, they are going to have the liquidity they need to service their debt. So there's more work to do on that front.

And just -- I don't want to steal your question, but I do want to just say, with respect to our budget, there's a reason why I'm spending this time out here in Asia and out here in the Pacific region. First and foremost, because this is the fastest-growing economic region in the world, and I want to create jobs in the United States, which means we've got to sell products here and invest here and have a robust trading relationship here, and Australia happens to be one of our strongest trading partners.

But the second message I'm trying to send is that we are here to stay. This is a region of huge strategic importance to us. And I've made very clear, and I'll amplify in my speech to Parliament tomorrow, that even as we make a whole host of important fiscal decisions back home, this is right up there at the top of my priority list. And we're going to make sure that we are able to fulfill our leadership role in the Asia Pacific region.

PRIME MINISTER GILLARD: And I was just going to make what I think is the common-sense point -- I'm not going to issue words of advice about the fiscal position in the United States -- but the common-sense point from the point of view of the leader is, ultimately, budgets are about choices and there are hard choices about the things you value. And I think, by President Obama being here, he is saying he values the role of the United States in this region and our alliance, and that's what the announcement we've made today is all about. 
We've got a question from Mark Riley from the Australian media.

Q Thanks, Prime Minister. Mark Riley from 7News, Australia. Mr. President, I wanted to ask you about the other rising giant of our region -- India -- and the Prime Minister might like to add some comments. How significant is it for the U.S. that Australia is now considering selling uranium to India? And could you clear up for us what influence or encouragement your administration gave Australia as it made that decision? And also, the decision is so India can produce clean energy. In that regard, you're aware that our Parliament has passed a new bill, pricing carbon -- a carbon tax, if you like. But we're intrigued about where America is going on this issue.

And countries like Australia don't see a carbon trading system in the world working unless America is a big part of it. Can you tell us, is it your wish that American will have an emissions trading scheme across the nation within the next five years or so? How heavily do you want to see America involved in an emissions trading scheme globally, or has this become too politically hard for you?

PRESIDENT OBAMA: Well, first of all, with respect to India, we have not had any influence, I suspect, on Australia's decision to explore what its relationship in terms of the peaceful use of nuclear energy in India might be. I suspect that you've got some pretty smart government officials here who figured out that India is a big player, and that the Australia-India relationship is one that should be cultivated. So I don't think Julia or anybody else needs my advice in figuring that out. This is part of your neighborhood, and you are going to make bilateral decisions about how to move forward.

I think without wading into the details, the discussions that are currently taking place here in Australia around that relationship and the nuclear issue with India are ones that are compatible with international law, compatible with decisions that were made in the NPT. And I will watch with interest what's determined. But this is not something between the United States and Australia; this is something between India and Australia. 
With respect to carbon emissions, I share the view of your Prime Minister and most scientists in the world that climate change is a real problem and that hum activity is contributing to it, and that we all have a responsibility to find ways to reduce our carbon emissions.

Each country is trying to figure out how to do that most effectively. Here in Australia, under the leadership of the Prime Minister, you've moved forward with a bold strategy. In the United States, although we haven't passed what we call a cap-and-trade system, an exchange, what we have done is, for example, taken steps to double fuel efficiency standard on cars, which will have an enormous impact on removing carbon from the atmosphere.

We've invested heavily in clean energy research. We believe very strongly that we've improved efficiencies and a whole step range of steps that we can meet and the commitments that we made in Copenhagen and Cancun. And as we move forward over the next several years, my hope is, is that the United States, as one of several countries with a big carbon footprint, can find further ways to reduce our carbon emissions. I think that's good for the world. I actually think, over the long term, it's good for our economies as well, because it's my strong belief that industries, utilities, individual consumers -- we're all going to have to adapt how we use energy and how we think about carbon.

Now, another belief that I think the Prime Minister and I share is that the advanced economies can't do this alone. So part of our insistence when we are in multilateral forum -- and I will continue to insist on this when we go to Durban -- is that if we are taking a series of step, then it's important that emerging economies like China and India are also part of the bargain. That doesn't mean that they have to do exactly what we do. We understand that in terms of per capita carbon emissions, they've got a long way to go before they catch up to us. But it does mean that they've got to take seriously their responsibilities as well.

And so, ultimately, what we want is a mechanism whereby all countries are making an effort. And it's going to be a tough slog, particularly at a time when 
the economies are -- a lot of economies are still struggling. But I think it's actually one that, over the long term, can be beneficial.

\section{Jackie Calmes.}

Q Thank you, Mr. President. Thank you, Prime Minister Gillard. I wanted to double back to the topic of China. It seems there's a bit of a schizophrenic aspect to this week of summitry in the Asian Pacific, where China is participating from Hawaii to Indonesia, but then you have all the rest of you who are talking about, on one hand, a trade bloc that excludes China, and now this -and an increased military presence for the United States, which is symbolized most by this agreement the two of you have made for a permanent U.S. presence in Australia.

What is it everyone fears so much from China? And isn't there some risk that you would increase tensions in a way that would take some of the -- China might take some of the very actions you fear?

PRIME MINISTER GILLARD: I'm happy to start with that and then go to the President. I don't -- I think there's actually a theme throughout the work we've been involved with at APEC, some of the discussion here and what we will take to the East Asia Summit. We may be on a journey from saying "aloha" to "good day" to "Bali hai*" or something like that. But I actually think in terms of a strategic outlook, it remains the same -- which is both of our nations deeply engaged with China as it rises and we want to see China rise into the global rules-based order.

That's our aspiration. I understand it to be the aspiration of the United States. It's something that we pursue bilaterally with China. It's something that we pursue multilaterally in the various forums that we work in.

This East Asia Summit will have a particular significance, coming for the first time with the President of the United States there and of course Russia represented around the table, so all of the players with the right mandate to discuss strategic, political and economic questions for our region. 
So I actually believe there's a continuity here: APEC fundamentally focused on trade and economic liberalization; here in Australia, longtime allies, talking about the future of their alliance and building for that future, as you would expect, but also preparing for a set of discussions in Bali, which will bring us together again with our friends across the region.

PRESIDENT OBAMA: Just to pick up on this theme, Jackie, I think the notion that we fear China is mistaken. The notion that we are looking to exclude China is mistaken. And I'll take TPP as a perfect example of this. We haven't excluded China from the TPP. What we have said is the future of this region depends on robust trade and commerce, and the only way we're going to grow that trade is if we have a high-standards trade agreement where everybody is playing by the same rules; where if one set of markets is open then there's reciprocity among the other trading partners; where there are certain rules that we abide by in terms of intellectual property rights protection or how we deal with government procurement -- in addition to the traditional areas like tariffs.

And what we saw in Honolulu, in APEC, was that a number of countries that weren't part of the initial discussions -- like Japan, Canada, Mexico -- all expressed an interest in beginning the consultations to be part of this highstandard trade agreement that could potentially be a model for the entire region.

Now, if China says, we want to consult with you about being part of this as well, we welcome that. It will require China to rethink some of its approaches to trade, just as every other country that's been involved in the consultations for the TPP have had to think through, all right, what kinds of adjustments are we willing to make?

And so that's the consistent theme here. This is a growing region. It is a vital region. The United States is going to be a huge participant in both economic and security issues in the Asia Pacific region, and our overriding desire is that we have a clear set of principles that all of us can abide by so that all of us can succeed. And I think it's going to be important for China to be a part of that. I think that's good for us. 
But it's going to require China, just like all the rest of us, to align our existing policies and what we've done in the past with what's needed for a brighter future.

PRIME MINISTER GILLARD: Thank you very much.

PRESIDENT OBAMA: Thank you very much, everybody.

PRIME MINISTER GILLARD: Thank you.

\section{END}

6:43 P.M. AEST 


\title{
Appendix (4)
}

\section{Transcript of joint press conference with US Secretary of State Hillary Clinton following their meeting in Washington D.C. (with Australian Minister for Foreign Affairs Senator the Hon Bob Carr)}

\author{
Washington D.C., USA
}

\section{Transcript, E\&OE, proof only}

\section{April 2012}

HILLARY CLINTON: Good afternoon, everyone. It is certainly a great pleasure for me to welcome Foreign Minister Carr here to Washington. It is always an incredibly important discussion between ourselves and our Australian friends and allies, and we've had a chance to cover a broad range of issues that we have a continuing consultation over. Before I mention those, however, I want to say a few words about Syria and the events of the past few days.

On Saturday, as you know, the UN Security Council voted unanimously to increase tenfold the number of monitors sent to Syria under Kofi Annan's plan. The onus is now on the regime to meet all of its commitments under that plan, including allowing the UN monitors to fully deploy and move throughout the country without restrictions. Unfortunately, the Assad regime has broken its commitments time and again, so even as we work to help deploy the monitors, we are preparing additional steps in case the violence continues or the monitors are prevented from doing their work.

Yesterday, President Obama announced a powerful new class of sanctions on individuals and companies in Syria, as well as in Iran, that use communications technologies to commit human rights abuses. Both of these steps send a clear signal that the international community will continue to pressure Assad and his regime as long as they insist on slaughtering their own people and denying a political transition.

With respect to today's meeting with Minister Carr and myself, it represents what is one of the world's strongest and most productive alliances. For more than 60 years, our relationship has been and remains vital, not only in the Asia-Pacific region but around the world. So it is fitting that we discussed a wide range of bilateral, regional, and global issues. We discussed the steps we are taking together to strengthen our military alliance, which helps underwrite security and stability in the Asia-Pacific. 
As President Obama and Prime Minister Gillard announced last year, U.S. Marines will begin rotating through Darwin for joint training and exercises. In fact, the first contingent of 200 Marines arrived earlier this month, and I thanked the Minister for the very warm welcome they received. We expect that these exercises will eventually expand to include other friends and partners in the region, which will strengthen our efforts to fight piracy and provide humanitarian assistance and disaster relief through the Asia-Pacific.

We also discussed the ongoing transition in Afghanistan. Australian troops have fought bravely alongside NATO and Afghan forces. Thirty-two Australian soldiers have lost their lives, and on the eve of Anzac Day we honour their memory.

Now while none of us are blind to the real challenges that remain before us, we know we are making tangible progress. Al-Qaida's leadership is decimated. We have opened the door for Afghan reconciliation, the Afghan people are taking responsibility for their own security, and we continue to meet our milestones for the transition agreed to by our leaders in Lisbon two years ago. But NATO and its partners cannot and will not abandon Afghanistan after 2014. Our ongoing support will be essential to preserving and building on the gains we've made thus far.

So to that end, representatives from the United States and Afghanistan have initialled a draft Strategic Partnership Agreement moving us closer to the completion of this process. While there is still some work to be done before our Presidents will be able to sign the agreement - including consultations with the Congress - there should be no doubt that the United States will remain a steadfast, long-term partner to the Afghan people as they continue rebuilding their country and fighting violent extremism.

As I said to the Foreign Minister today, we are hoping that by the NATO summit in Chicago, other partners will also be making their commitments to the future of Afghanistan. The Afghan National Security Force will need some \$1.3 billion from the international community to sustain their efforts over the coming year that will be added to the $\$ 500$ million committed by the Afghans and the commitment that the United States is making.

I welcomed Prime Minister Gillard's statement last week committing to support the Afghan National Security Forces after 2014, and I look forward to working 
with Australia and other partners on ways to make sure that any funds are spent transparently and with full accountability.

Finally, we discussed a number of regional issues, including North Korea's recent missile launch, the encouraging political and economic reforms taking place in Burma. We are both working to try to assist the reform process in Burma. We also discussed ways to better coordinate our engagement in the Pacific Islands as well as upcoming efforts at the ASEAN Regional Forum in Cambodia.

So Foreign Minister, thank you for making us a stop on your whirlwind global tour, and I look forward to continuing to work closely with you.

BOB CARR: Thank you Secretary of State. It's been a great honour for me to visit and in this capacity. I've long been an admirer of yours and your contribution to public life. I was honoured to welcome you to Sydney in 1996 and show you a bit of Sydney Harbour and give a speech of welcome to you and President Clinton. It's nice to be here in another capacity, nice to be with you in another capacity.

The relationship between us and the United States rests on a broad and enduring community of common values and shared interests. It's a relationship between two of the oldest democracies in the world. On the Gettysburg battlefield on Sunday with Ambassador Beazley, I was reminded of the soaring words of Lincoln "government of the people" and that's what unites us. This nation, the United States, conceived the Constitution in the 1790s to give effect to that notion of government by the people. And Australians have adhered to democratic values ever since we won self-government in the middle of the 19th century. And that on the bottom line is what makes us respond to one another and find one another such comfortable allies.

It was a great pleasure to talk through all these matters of common interest with the Secretary of State today and she and I would invite your questions.

MEDIATOR: We'll start today with CNN, Jill Dougherty.

QUESTION: Thank you very much. Madam Secretary, you mentioned Syria and just before we came up here, Ahmad Fawzi, the spokesperson for Kofi Annan, said that they have credible reports that when the monitors go into places and then leave, that the people, the civilians who have approached them, talked with them, or met with them, are having very serious problems, that they're being 
harassed, arrested, and possibly even killed. Do you have any indication from U.S. sources that this is the case? If this is the case, what can be done? Because you said, "next steps," but I think everybody feels at this point, when is enough, enough?

And then just another intractable issue that seems to be coming at this - at the same time is Sudan and South Sudan. And you have the steps today, we were talking at the briefing, South Sudan pulls out of Heglig and Sudan takes advantage of that. This is another question that begs that when is enough. Or in this case, when - how can you pull these two countries together?

SECRETARY CLINTON: Well Jill, first, with respect to Syria, before coming out here I saw the reports from Kofi Annan's spokesperson, and it is absolutely deplorable if there is this kind of intimidation, harassment, and possible violence against those Syrians who have every right to meet with and discuss the situation with the monitors. That's what the monitors are there for.

And as I said, Syria is at a crossroads. We supported Kofi Annan's plan. No one stands to gain if the plan fails. In fact, the only sources - or the only potential gainers would be the enemies of peace and change. So the bulk of the responsibility rests with Assad and with his supporters and his military to demonstrate a commitment to the Annan plan by silencing the guns, making sure that they're on a path toward the six points that Kofi Annan has set forth, which the Syrians claim they agree with, including a political transition.

So we have continued consulting closely with our friends and allies in the region and beyond about what additional steps could be taken, but we would like to see Kofi Annan's plan succeed. It clearly cannot succeed unless all Syrians are permitted to take advantage of the presence of the UN monitors as they begin their mission.

So I strongly condemn the reports that we heard earlier today and want to be kept totally informed about what is happening inside Syria, because the entire world is watching. The Syrian Government made a commitment to not only permit the UN monitoring mission to go forward but to work on the Kofi Annan plan, and we expect them to comply.

Regarding Sudan and South Sudan, we are very concerned about what is happening in the region, particularly along the border. We also have spoken out strongly against the bombing of civilians being carried out by the Government of Sudan in South Sudan beyond the border area, most recently in Bentiu. They are 
are provocative and unacceptable actions. South Sudan did withdraw from Heglig. It presented an opportunity for Khartoum to resume negotiations and to make real progress between North and South, and we urge both parties to undertake that as soon as possible.

So what are the next steps? The next steps are a ceasefire, a withdrawal of armed groups from both sides, and a resumption of talks. That's the message that we, the African Union, and the international community are all conveying to the parties. We have been reaching out continuously to the South. Others have been reaching out to the North. And we understand how difficult the unresolved issues are between Khartoum and Juba. But no matter how difficult the negotiation ahead may be, it is far preferable to war, and we are adamant in calling on both sides to immediately engage in a ceasefire and withdrawal, as the South did from Heglig, and restart those talks.

MEDIATOR: Last one today, Brad Norington from the Australian.

Thank you. Secretary Clinton can you tell us your thoughts when you found that your Australian counterpart was suddenly, perhaps inexplicitly, no longer Kevin Rudd and someone you'd got to know reasonably well but now Bob Carr, former State Premier of New South Wales who had retired from politics. And Senator Carr, it made headlines internationally and in Australia last week when the Gillard government announced troops would be withdrawn from Afghanistan in 2013 - a year earlier than previously intended. There are now considerable efforts by the Australian government to say there's no change. Could you tell us what is it? And how did you explain it to Secretary Clinton?

SECRETARY CLINTON: Well, let me say I am delighted to work with Minister Carr. I very much appreciated the good working relationship I had with Kevin Rudd. We tackled a number of difficult issues. I'm picking up with Bob Carr right where we left off with Kevin Rudd. The relationship between our two countries is broad and deep and enduring and each government determines who will fill that position but it's not about any individual. It's about the character of our alliance and the strength of our partnership and frankly the friendship that we enjoy with one another.

And as Minister Carr said, I have very fond memories of his welcoming me to Sydney. I have also very great appreciation for his kindness to my daughter when she attended the Olympics. I am partial to political people and I think those who are retired certainly have a lot still to do in their lives. (Laughter). So I would 
only express the greatest appreciation for the opportunity to continue working closely with my Australian counterpart.

BOB CARR: The message I've had since I took over as Australian Foreign Minister barely six weeks ago is one of continuity. I'm continuing the work of Kevin Rudd. This continuity runs through years of Australian foreign policy and what we're about here, working on the Australian American partnership, is bipartisan consensus in Australia. And I emphasise the continuity here.

I didn't have to explain what Prime Minister Gillard said - I've got her speech here. And in Brussels last week, as soon as I walked into General Allen's office he said "I've read the Prime Minister's speech. It was an excellent speech" and the same with Admiral Stavridis in Brussels. And the Secretary of State is familiar with what the Prime Minister said. I won't detain you by giving out the key pages but made it very, very clear - there is no premature Australian withdrawal. There is a commitment to a process of transition in light of what was agreed on in Lisbon. And that was made perfectly clear by the Prime Minister.

There is confusion in some sections of the media between the notion of transition and withdrawal, the same thing happened to Defense Secretary Panetta earlier this year but I had no explanation I had to give the Secretary of State because she was familiar with the Prime Minister's speech and understood perfectly, as had everyone else in the US Administration with whom I've spoken. 